\title{
KONTRIBUSI PENERIMAAN PENDAPATAN SEKTOR PARIWISATA TERHADAP \\ PENDAPATAN ASLI DAERAH (PAD) \\ KOTA BANDUNG
}

\author{
Rieke Sri Rizki Asti Karini ${ }^{1}$ \\ STIEPAR YAPARI BANDUNG \\ rsrak17@yahoo.com \\ Indah Nur Agustiani ${ }^{2}$ \\ STIEPAR YAPARI BANDUNG \\ Indahmuchtar19@yahoo.com
}

\begin{abstract}
ABSTRAK
Pendapatan Asli Daerah merupakan salah satu Pendapatan Daerah yang paling penting bagi suatu daerah.Salah satu sektor potensial yang dapat digali sebagai sumber Pendapatan Asli Daerah adalah sektor pariwisata yang berkontribusi terhadap Pajak Daerah melalui pajak hotel, pajak restoran, dan pajak hiburan.Penelitian ini dilakukan untuk melihat seberapa besar pengaruh pendapatan sektor pariwisata terhadap Pendapatan Asli Daerah Kota Bandung. Data yang digunakan dalam penelitian ini adalah data sekunder yaitu data realisasi pajak hotel, pajak restoran, pajak hiburan dan Pendapatan Asli Daerah tahun 2011-2015.Adapun metode penelitian yang digunakan adalah metode penelitian deskriptif dan verifikatif dengan pendekatan kuantitatif.Rancangan pengujian hipotesis dalam penelitian ini terdiri dari analisis regresi linear berganda, koefisien determinasi, uji t (parsial) dan uji F (simultan). Hasil penelitian menunjukkan bahwa secara parsial pajak hotel, pajak restoran, dan pajak hiburan tidak memiliki pengaruh signifikan terhadap Pendapatan Asli Daerah namunsecara simultan pajak hotel, pajak restoran, dan pajak hiburan merupakan komponen pendapatan sektor pariwisata berpengaruh secara signifikan terhadap Pendapatan Asli Daerah.
\end{abstract}

Kata kunci : Pendapatan Sektor Pariwisata, Pajak Hotel, Pajak Restoran, Pajak Hiburan, Pendapatan Asli Daerah 


\title{
CONTRIBUTION OF TOURISM SECTOR REVENUE ACCEPTANCE ON BANDUNG ORIGINAL LOCAL REVENUE
}

\begin{abstract}
The original local revenues is one of the most important income for an area. One of the potential sectors that can be explored as a source of the original local revenue is tourism sectors that contributes to local taxes through hotel's tax, restaurant's tax, and entertainment's tax. This research was conducted to see how big the influence of tourism sector's income on Bandung original local revenue. Data used in this research was secondary data, namely the realization of of hotel tax data, restaurant tax data, entertainment tax data, and the original local revenues in 2011-2015. As for research method used is descriptive and verification method with quantitative approach. The design of hypothesis testing in this research consisted of multiple linear regression analysis, coefficient of determination, $\mathrm{t}$ test (partial), and $\mathrm{f}$ test (simultaneous). The results of this research showed that the partially hotel's tax, restaurant's tax, and entertainment's tax do not have significant influence effect the original local revenue. Simultaneously, hotel's tax, restaurant's tax, and entertainment's tax which is a component of tourism sector's income influential significantly on the original local revenue
\end{abstract}

Keywords : An Income of Tourism Sector, Hotel's Tax, Restaurant's Tax, Entertainment's Tax, The Original Local Revenue.

\section{PENDAHULUAN}

Pembangunan nasional Indonesia bertujuan mewujudkan masyarakat adil makmur melalui peningkatan taraf hidup, kecerdasan dan kesejahteraan seluruh rakyat.Dalam rangka mewujudkannya, maka pelaksanaan pembangunan harus merata di seluruh tanah air yang tidak terlepas dari peran serta daerah dalam mewujudkan tujuan pembangunan secara utuh dan terpadu yang merupakan bagian integral pembangunan nasional.

Indonesia memiliki potensi pariwisata sangat besar.Keindahan alam, keunikan budaya dan beragam kesenian merupakan aset menjanjikan dalam pengembangan pariwisata. Pariwisata memiliki peran penting dalam menunjang perekonomian sebagai katalisator terhadap perekonomian negara. Dalam pengembangannya, Pemerintah Daerah sebagai kepanjangan tangan Pemerintah Pusat dalam mengelola potensi wisata daerah harus dapat memberikan kontribusi optimal baik bagi pengusaha, masyarakat dan pemerintah. Hal ini diperkuat dengan adanya komitmen pemerintah dalam RPJMN 2010-2014 (Rencana Tata Ruang Wilayah Nasional dan Prioritas Nasional Lainnya di Indonesia). 
Keberhasilan pengembangan sektor kepariwisataan berarti akan meningkatkan perannya dalam penerimaan daerah, dimana kepariwisataan merupakan komponen utama (Salah, 2003:16).

Pemerintah Daerah dapat memanfaatkan Anggaran Pendapatan dan Belanja Daerah (APBN) yang salah satunya didapat dari Anggaran Pendapatan Asli Daerah(PAD).PAD mempresentasikan kemandirian daerah dan kedewasaan dalam mengelola dan menemukan potensi pendapatan daerah sebagai sumber keuangan dalam membiayai pembangunan di daerah sesuai dengan sistem otonomi daerah yang tidak hanya diukur dari jumlah PAD yang dicapai, namun sejauh mana pajak yang dipungut dapat meningkatkan kesejahteraan masyarakat di daerah. Untuk itu, daerah diberi kewenangan mengatur daerahnya sendiri sehingga memiliki kemampuan dalam menyediakan dan menggali potensi yang ada. Dengan dimanfaatkannya potensi dan peluang pariwisata menjadi industri diharapkan mampu meningkatkan Pendapatan Asli Daerah sebagai sumber pembiayaan pembangunan daerahmelalui pajak yang diterima.

Pajak merupakan salah satu sumber dari penerimaan negara dalam melaksanakan pembangunan.Dipungut dari WNI yang menjadi kewajiban yang dapat dipaksakan penagihannya.Pembangunan nasional pada dasarnya dilakukanbersama-sama antara masyarakat dan pemerintah sehingga peran masyarakat dalam pembiayaan pembangunan ditumbuhkan dengan meningkatkan kesadaran masyarakat tentang kewajibannya membayar pajak.Pembagian pajak menurut wewenangnya dipisahkan menjadi dua yaitu pajak pusat dan pajak daerah.Pajak pusat dipungut Pemerintahan Pusat terdiri dari PPh dan PPn. Sedangkan untuk pajak daerah dipungut oleh Pemerintah Daerah.

Secara operasional, esensi dari Undang-Undang Nomor 28 Tahun 2009 tentang Pajak Daerah dan Retribusi Daerah sebagai landasan struktural dan operasional pengenaan pajak di daerah membawa konsekuensi Pemerintah Daerah (Kabupaten/Kota) untuk mengoptimalkan pengelolaan potensi yang dimilikinya dalam mengeksploitasi pendapatan pajak daerah. Salah satunya adalah sektor pajak daerah memberikan kontribusi terhadap penerimaan daerah yang digunakan sebagai sumber dana/biaya belanja daerah. Pajak daerah yang dimaksud meliputi pajak hotel, pajak restoran, pajak hiburan, pajak reklame, pajak penerangan jalan, pajak parkir, pajak air tanah, bea perolehan hak atas tanah dan bangunan, pajak bumi dan bangunan pedesaan dan perkotaan.

Pendapatan dari sektor pariwisata yang meliputi pajak hotel, pajak restoran, dan pajak hiburan yang memberikan berkontribusi terbesar terhadap PAD Kota Bandung yang memiliki wisata belanja, kuliner, dan lokasi-lokasi hiburan sebagai andalannya. Ragam wisata ini mampu menarik minat wisatawan domestik dan mancanegara datang ke Bandung sehingga tingkat kunjungan mengalami peningkatan signifikan dari tahun ke tahun.

Data menunjukkan penerimaan pajak dari sektor pariwisata dan Pendapatan Asli Daerah dalam tiga tahun terakhir yaitu dari tahun 2013-2015 pada tabel 1 dan 2 sebagai berikut: 
Tabel 1.

Target dan Realisasi Penerimaan Pendapatan Sektor Pariwisata

Tahun Anggaran 2013-2015

\begin{tabular}{|c|c|c|r|r|r|r|}
\hline \multirow{2}{*}{$\begin{array}{c}\text { Pajak Dari Sektor } \\
\text { Pariwisata }\end{array}$} & \multicolumn{2}{|c|}{$\mathbf{2 0 1 3}$} & \multicolumn{2}{c|}{$\mathbf{2 0 1 4}$} & \multicolumn{2}{c|}{$\mathbf{2 0 1 5}$} \\
\cline { 2 - 7 } & Target & \multicolumn{1}{|c|}{ Realisasi } & \multicolumn{1}{c|}{ Target } & \multicolumn{1}{c|}{ Realisasi } & \multicolumn{1}{c|}{ Target } & \multicolumn{1}{c|}{ Realisasi } \\
\hline Pajak Hotel & 148.000 .000 .000 & 177.490 .303 .830 & 202.850 .000 .000 & 204.152 .062 .826 & 260.000 .000 .000 & 215.285 .361 .236 \\
\hline Pajak Restoran & 102.000 .000 .000 & 118.700 .322 .856 & 140.000 .000 .000 & 142.399 .711 .300 & 170.000 .000 .000 & 181.401 .845 .809 \\
\hline Pajak Hiburan & 35.500 .000 .000 & 37.767 .188 .531 & 45.000 .000 .000 & 40.730 .151 .211 & 60.000 .000 .000 & 50.429 .747 .411 \\
\hline Jumlah & 285.500 .000 .000 & 333.957 .815 .217 & 387.850 .000 .000 & 387.281 .925 .337 & 490.000 .000 .000 & 447.116 .954 .456 \\
\hline
\end{tabular}

Sumber: Dinas Pelayanan Pajak (Disyanjak) Kota Bandung (2018)

Dari tabel diatas secara keseluruhan terlihat penerimaan sektor pariwisata diTahun Anggaran 2013 dan 2015 mencapai target yang diharapkan, sedangkan di Tahun Anggaran 2014 tidak mencapai target yang diharapkan.

Tabel 2

Target dan Realisasi Pendapatan Asli Daerah Kota Bandung Tahun Anggaran 2013-2015

\begin{tabular}{|c|c|r|c|}
\hline Tahun Anggaran & Target PAD & Realisasi PAD & \% Dari Sektor Pariwisata \\
\hline 2013 & 148.000 .000 .000 & 177.490 .303 .830 & $23,14 \%$, \\
\hline 2014 & 202.850 .000 .000 & 204.152 .062 .826 & $22,61 \%$, \\
\hline 2015 & 260.000 .000 .000 & 215.285 .361 .236 & $22,78 \%$. \\
\hline Jumlah & $\mathbf{6 1 0 . 8 5 0 . 0 0 0 . 0 0 0}$ & $\mathbf{5 9 6 . 9 2 7 . 7 2 7 . 8 9 2}$ & $\mathbf{6 8 . 5 3 \%}$ \\
\hline
\end{tabular}

Sumber: Dinas Pelayanan Pajak (Disyanjak) Kota Bandung (2018)

Berdasarkan target dan realisasi PAD Kota Bandung, pada tahun anggaran 2013 dan 2014 realisasi PAD melebihi targetnya. Namun pada tahun 2015, realisasi PAD dibawah target yang diharapkan. Terkait dengan tabel diatas, khususnya Pajak Hotel di tahun 2015, Dinas Pelayanan Pajak (Disyanjak) Kota Bandung menduga adanyapenggelapanpajakyang dilakukan pengusaha hotel sehingga pelaksanaan realisasi sangat jauh dari target yang ditetapkanDinas Pelayanan Pajak (Disyanjak) Kota Bandung. Selain itu, adanya kebijakan Pemerintah Kota Bandung yang melarangpenggunaan fasilitas hotel dalam mengadakan rapat, pembatasan jam operasional tempat hiburan, 9 WPmenutup tempat hiburan dan 4 WP yang menutup sementara tempat hiburan serta occupancy yang menurun membuat pendapatan di sektor pariwisata menurun pada tahun 2015.

Berdasarkan fenomena penerimaan pendapatan sektor pariwisatasebagai salah satu sumber Pendapatan Asli Daerah Pemerintah Kota Bandung, maka penulis tertarik untuk menganalisis kontribusi penerimaan pendapatan sektor pariwisata Kota Bandung pariwisata terhadap Pendapatan Asli Daerah Kota Bandung.

\section{Konsep Pajak}

Pajak merupakan iuran negara yang terutang oleh wajib pajak orang pribadi atau badan yang bersifat memaksa untuk kepentingan masyarakat dalam pembangunan dan 
penyelenggaraan pemerintah yang diatur berdasarkan peraturan perundang-undangan. Soemitro dalam Mardiasmo (2011:1) menyatakan bahwa "Pajak adalah iuran rakyat kepada kas negara berdasarkan undang-undang (yang dapat dipaksakan) dengan tiada mendapat jasa timbal (kontraprestasi) yang langsung dapat ditunjukkan dan yang digunakan untuk membayar pengeluaran umum".

Menurut Mardiasmo (2011:1-2) terdapat dua fungsi pajak, diantaranya:

1. Fungsi budgetair, yaitu pajak sebagai sumber dana bagi pemerintah untuk membiayai pengeluaran-pengeluarannya.

2. Fungsi mengatur (regulerend) yaitu pajak sebagai alat untuk mengatur atau melaksanakan kebijaksanaan dalam bidang sosial dan ekonomi.

Dari pernyataan diatas disimpulkan bahwa pajak menjadi sumber dana dan alat melaksanakan kebijaksanaan bagi pemerintah. Pajak yang dikumpulkan digunakan pembiayaan rutin seperti pemeliharaan, untuk pembiayaan pembangunan dan lain sebagainya.

Selain itu, pajak dimanfaatkan untuk pembangunan pariwisata seperti:

1. Investasi infrastruktur : Bandara, Jalan raya, dermaga dll.

2. Fasilitas pembangunan pariwisata, pengeluaran pemerintah dalam pembangunan pariwisata: subsidi atau bantuan, bunga bank, bantuan penelitian, bantuan pendidikan dan pelatihan, bebas pajak bagi barang atau jasa tertentu, jaminan atau garansi, jaminan ijin atas pekerja asing, dan lain - lain.

3. Pemasaran pariwisata: Riset dan kegiatan pemasaran, Public Relation, Iklan dan Promosi lainnya, Komunikasi dan distribusinya, Pengembangan produk, dll.

Menurut Mardiasmo (2011:5-6) pengelompokan pajak terdiri dari:

1. Menurut golongannya

a. Pajak langsung, yaitu pajak yang harus dipikul sendiri oleh Wajib Pajak dan tidak dapat dibebankan atau dilimpahkan kepada orang lain. Contoh: Pajak Penghasilan (PPh).

b. Pajak tidak langsung, yaitu pajak yang pada akhirnya dapat dibebankan atau dilimpahkan kepada orang lain. Contoh: Pajak Pertambahan Nilai (PPn).

2. Menurut Sifatnya

a. Pajak Subjektif, yaitu pajak yang berpangkal atau berdasarkan pada subjeknya, dalam arti memperhatikan keadaan diri Wajib Pajak. Contoh: Pajak Penghasilan.

b. Pajak Objektif, yaitu pajak yang berpangkal pada objeknya, tanpa memperhatikan keadaan diri Wajib Pajak. Contoh: PPn dan PPnBM.

3. Menurut Lembaga Pemungutnya

a. Pajak Pusat, yaitu pajak yang dipungut oleh pemerintah pusat dan digunakan untuk membiayai rumah tangga negara. Contoh: PPh, PPn dan PPnBM, dan Bea Materai. 
b. Pajak Daerah yaitu pajak yang dipungut oleh Pemerintah Daerah dan digunakan untuk membiayai rumah tangga daerah. Pajak daerah terdiri atas:

1). Pajak Propinsi. Contoh: Pajak Kendaraan Bermotor dan Pajak Bahan Bakar Kendaraan Bermotor.

2). Pajak Kabupaten/Kota. Contoh: Pajak Hotel, Pajak Restoran, dan Pajak Hiburan.

\section{Pajak Daerah}

Dasar Hukum: UU No. 28 Tahun 2009 tentang Pajak Daerah dan Retribusi Daerah.

Menurut Suandy (2011:226) menyatakan bahwa "Pajak Daerah adalah iuran yang wajib dilakukan oleh orang pribadi atau badan kepada derah tanpa imbalan langsung yang seimbang, yang dapat dipaksakan berdasarkan peraturan perundang-undangan yang berlaku, yang digunakan untuk membiayai penyelenggaraan pemerintahan daerah dan pembangunan daerah".

Menurut UU Nomor 28 Tahun 2009 dinyatakan bahwa Pajak Daerah adalah kontribusi wajib kepada daerah yang terutang oleh orang pribadi atau badan yang bersifat memaksa berdasarkan Undang-Undang dengan tidak mendapatkan imbalan secara langsung dan digunakan untuk keperluan daerah bagi sebesar-besarnya kemakmuran rakyat.

Menurut Mardiasmo (2011:13) menyatakan bahwa jenis-jenis pajak daerah sebagai berikut:

1. Pajak Provinsi, terdiri dari: (a) Pajak Kendaraan Bermotor, (b). Bea Balik Nama Kendaraan Bermotor, (c) Pajak Bahan Bakar Kendaraan Bermotor, (d) Pajak Air Permukaan, dan (e) Pajak Rokok

2. Pajak Kabupaten/Kota, terdiri dari: (a). Pajak Hotel, (b) Pajak Restoran, (c) Pajak Hiburan, (d) Pajak Reklame, (e) Pajak Penerangan Jalan, (f) Pajak Mineral Bukan Logam dan Batuan, (g) Pajak Parkir, (h) Pajak Air Tanah, (i) Pajak Sarang Burung Walet, (h) Pajak Bumi dan Bangunan Pedesaan dan Perkotaan dan (k) Bea Perolehan Hak atas Tanah dan Bangunan

Khusus daerah setingkat daerah provinsi, tetapi tidak terbagi dalam daerah kabupaten/ kota otonom, seperti Daerah Khusus Ibukota Jakarta, jenis pajak yang dipungut merupakan gabungan dari pajak untuk daerah provinsi dan pajak kabupaten/kota.

Berdasarkan Peraturan Daerah Kota Bandung Nomor 20 Tahun 2011, jenis Pajak Daerah yang diatur meliputi: (a) Pajak Hotel, (b) Pajak Restoran, (c) Pajak Hiburan, (d) Pajak Reklame, (e) Pajak Penerangan Jalan (f). Pajak Parkir, (g) Pajak Air Tanah, (h) Bea Perolehan Hak atas Tanah dan Bangunan dan (i) Pajak Bumi dan Bangunan Perdesaan dan Perkotaan 
Mardiasmo (2011:13) menyatakan bahwa tarif tertinggi setiap jenis pajak kabupaten/ kota adalah: (a) Tarif Pajak Rokok ditetapkan 10\% dari cukai rokok, (b) Tarif Pajak Hotel ditetapkan 10\%, (c) Tarif Pajak Restoran ditetapkan 10\%, (d) Tarif Pajak Hiburan ditetapkan 35\%, (e) Tarif Pajak Reklame ditetapkan sebesar 25\%, dan (f) Tarif Pajak Penerangan Jalan ditetapkan sebesar 10\%.

Dalam UU No. 20 Tahun 2000 dinyatakan bahwa Penetapan tarif pajak propinsi berbeda dengan penetapan tarif pajak kabupaten/kota yang ditetapkan dengan Peraturan Daerah. Tarif pajak kabupaten/kota ditetapkan dengan memperhatikan kondisi kabupaten/ kota dan pertimbangan tarifberbeda untuk jenis pajak kabupaten/kota tidak mempengaruhi pilihan lokasi Wajib Pajak untuk melakukan kegiatan yang dikenakan pajak

\section{Pengertian, Dasar Pengenaan, Tarif, Besaran Pokok Pajak Hotel}

Pengertian Pajak Hotel sesuai UU No. 28 Tahun 2009 disebutkan bahwa: "Pajak Hotel adalah pajak atas pelayanan yang disediakan oleh hotel. Pemungutan Pajak Hotel di Indonesia didasarkan UU No.34 Tahun 2000 merupakan perubahan atas UU No. 18 Tahun 1997 tentang Pajak Daerah dan Retribusi Daerah dan PP No 65 Tahun 2001 tentang Pajak Daerah.

Peraturan Daerah Kota Bandung Nomor 20 Tahun 2011 menyatakan bahwa dasar pengenaan Pajak Hotel adalah jumlah pembayaran atau yang seharusnya dibayar kepada hotel.

Lebih lanjut, dalam Peraturan Daerah dalam Kota Bandung Nomor 20 Tahun 2011 dinyatakan tarif Pajak Hotel ditetapkan sebagai berikut:

a. Hotel, Motel, Losmen, Gubuk pariwisata, Wisma pariwisata, Pesangrahan, Rumah penginapan dan sejenisnya ditetapkan sebesar 10\% (sepuluh persen);

b. Rumah Kos dengan Jumlah Kamar 11 (sebelas) s/d 20 (dua puluh) Kamar ditetapkan sebesar 5\% (lima persen);

c. Rumah Kos dengan Jumlah Kamar diatas 20 (dua puluh) Kamar ditetapkan sebesar 7\% (tujuh persen).

Menurut Peraturan Daerah Kota Bandung Nomor 20 Tahun 2011 dinyatakan besaran pokok Pajak Hotel yang terutang dihitung dengan cara mengalikan Tarif dengan Dasar Pengenaan Pajak

\section{Pengertian, Dasar Pengenaan, Tarif ,Besaran Pokok Pajak Restoran}

Menurut Peraturan Daerah Kota Bandung Nomor 20 Tahun 2011 dinyatakan bahwa pajak restoran adalah pajak atas pelayanan yang disediakan oleh restoran. Sedangkan yang dimaksud dengan restoran adalah fasilitas penyedia makanan dan atau minuman 
dengan dipungut bayaran, yang mencakup juga rumah makan,kafetaria, kantin, warung, bar, dan sejenisnya termasuk jasa boga/katering.

Peraturan Daerah Kota Bandung Nomor 20 Tahun 2011 menyatakan bahwa Dasar Pengenaan Pajak Restoran adalah jumlah pembayaran yg diterima / yg seharusnya diterima restoran. Lebih lanjut, dalam Peraturan Daerah Kota Bandung Nomor 20 Tahun 2011 dinyatakan bahwa tarif Pajak Restoran ditetapkan sebesar 10\% (sepuluh persen). Peraturan Daerah Kota Bandung Nomor 20 Tahun 2011 dinyatakan bahwa besaran pokok Pajak Restoran yang terutang dihitung dengan cara mengalikan tarif sebagaimana dimaksud dalam Pasal 11 dengan dasar pengenaan pajak

\section{Pengertian, Dasar Pengenaan, Tarif Pajak Hiburan, Besaran Pokok Pajak Hiburan}

Peraturan Daerah Kota Bandung Nomor 20 Tahun 2011 menyatakan bahwa pengertian Pajak Hiburan adalah pajak atas penyelenggaran hiburan.Sedangkan yang dimaksud dengan hiburan adalah semua jenis tontonan, pertunjukan, permainan dan/atau keramaian yang dinikmati dengan dipungut bayaran.

Peraturan Daerah Kota Bandung Nomor 20 Tahun 2011 menyatakan bahwa Dasar Pengenaan Pajak Hiburan adalah jumlah uang yang diterima atau yang seharusnya diterima oleh penyelenggaran hiburan. Jumlah uang yang seharusnya diterima yang dimaksud termasuk potongan harga dan tiket cuma-cuma yang diberikan kepada penerima jasa hiburan.

Lebih lanjut, dalam Peraturan Daerah Kota Bandung Nomor 20 Tahun 2011 dinyatakan bahwa Tarif Pajak Hiburan ditetapkan sebesar:

a. Tontonan film: (1) Harga tiket masuk dengan harga diatas Rp. 50.000,- (lima puluh ribu rupiah) ditetapkan sebesar 15\% (lima belas persen), (2) Harga tiket masuk mulai harga Rp. 10.000,- (sepuluh ribu rupiah) sampai dengan Rp. 50.000,- (lima puluh ribu rupiah) ditetapkan sebesar 10\% (sepuluh persen); dan (3) Harga tiket masuk dibawah Rp. 10.000,- (sepuluh ribu rupiah) ditetapkan sebesar 7,5\% (tujuh koma lima persen).

b. Pagelaran kesenian, musik, tari modern, dan/ atau busana ditetapkan sebesar $10 \%$ (sepuluh persen) dari harga tiket masuk atau jumlah uang yang seharusnya diterima;

c. Binaraga dan sejenisnya ditetapkan sebesar $25 \%$ (dua puluh lima persen) dari harga tiket masuk atau jumlah uang yang seharusnya diterima;

d. Pameran yang bersifat komersil ditetapkan sebesar 15\% (lima belas persen) dari harga tiket masuk atau jumlah uang yang seharusnya diterima;

e. Diskotik, karaoke, klab malam,pub, dan sejenisnya ditetapkan sebesar 35\% (tiga puluh lima persen) dari jumlah pembayaran atau jumlah uang yang seharusnya diterima; 
f. Sirkus, akrobat, dan sulap ditetapkan sebesar 10\% (sepuluh persen) dari harga tiket masuk atau jumlah uang yang seharusnya diterima;

g. Permainan bilyar dan boling ditetapkan sebesar 15\% (lima belas persen) dari jumlah uang yang seharusnya diterima;

h. Pacuan kuda, kendaraan bermotor, dan permainan ketangkasan dewasa ditetapkan sebesar 25\% (dua puluh lima persen) dari harga tiket masuk atau jumlah uang yang seharusnya diterima;

i. Panti pijat, refleksi dan mandi uap/spa ditetapkan sebesar $25 \%$ (dua puluh lima persen) dari jumlah uang yang seharusnya diterima;

j. Khusus pusat kebugaran (fitness centre) ditetapkan sebesar 10\% (sepuluh persen) dari jumlah uang yang seharusnya diterima;

k. Pertandingan olahraga ditetapkan sebesar $10 \%$ (sepuluh persen) dari jumlah uang yang seharusnya diterima

Dalam Peraturan Daerah Kota Bandung Nomor 20 Tahun 2011 dinyatakan bahwa Besaran pokok Pajak Hiburan yang terutang dihitung dengan cara mengalikan tarif sebagaimana dimaksud dalam Pasal 16 dengan dasar pengenaan pajak sebagaimana dimaksud dalam Pasal 15.

\section{Pendapatan Asli Daerah (PAD)}

Menurut UU No.28 Tahun 2009 tentang Pajak Daerah dan Retribusi Daerah dinyatakan bahwa Pendapatan Asli Daerah merupakan pendapatan yang diperoleh daerah yang dipungut berdasarkan Peraturan Daerah sesuai dengan peraturan perundangundangan. Sumber PAD merupakan sumber keuangan daerah yang digali dalam wilayah daerah yang bersangkutan, yang terdiri dari : (a) Pajak Daerah, (b) Retribusi Daerah, (c) Bagian Laba Badan Usaha Milik Daerah dan (d) Lain-Lain Pendapatan Asli Daerah yang sah diantaranya hasil penjualan kekayaan daerah, pendapatan bunga, keuntungan selisih nilai tukar rupiah terhadap mata uang asing, ataupun bentuk lain sebagai akibat dari penjualan atau pengadaan barang dan jasa oleh daerah.

Siahaan (2013:11) menyatakan bahwa faktor-faktor yang mempengaruhi perkembangan penerimaan Pajak Daerah terhadap Pendapatan Asli Daerah (PAD) disebabkan faktor ekonomi (tingkat kemakmuran masyarakat, inflasi, kondisi sosial perekonomian daerah dan faktor non-ekonomi yaitu pendapatan sumber-sumber yang ada, tata cara pemungutan, pengawasan terhadap pelaksanaan pemungutan). Rendahnya tingkat kesadaran Wajib Pajak, tidak dilakukannya pemutakhiran data subjek dan objek pajak secara periodik, masih ada pegawai pemungut pajak berlatar belakang pendidikannya tidak dari perpajakan, masih ada SDM belum memahami tupoksinya dan kemampuan pegawai pemungutan pajak daerah relatif masih rendah. 
Sedangkan Thamrin dalam Siti Muharomah (2006) terdapat 4 hal yang berpengaruh terhadap PAD diantaranya adalah (1) Kondisi awal suatu daerah atau besar kecilnya keinginan Pemerintah Daerah untuk menetapkan pungutan dan kemampuan masyarakat, (2) Peningkatan cakupan atau ekstensifikasi dan intensifikasi penerimaan PAD, (3) Pembangunan baru, dan (4) Perubahan peraturan.

\section{Kontribusi Sektor Pariwisata TerhadapPendapatan Asli Daerah (PAD)}

Sektor pariwisata merupakan salah satu potensi daerah yang harus dikelola sehingga bisa berkontribusi terhadap Pendapatan Asli Daerah (PAD). Hal ini sejalan pernyataan Roerkarts and Savat dalam Spillane (1987) bahwa sektor pariwisata dapat memberikan manfaat, diantaranya : (a) menambah pemasukan dan pendapatan baik untuk Pemerintah Daerah maupun masyarakatnya, (b) membuka lapangan kerja, (c) menambah devisa Negara, (d) merangsang pertumbuhan kebudayaan asli dan (e) menunjang gerak pembangunan daerah. Adapun Pendapatan Asli Daerah(PAD) digunakan untuk membiayai pembangunan otonomi daerah masing-masing. Hal ini sejalan dengan pernyataan Gde Bhaskara Perwira Jaya dan AA Bagus Putu Widanta (2014) bahwa penerimaan pemerintah dari PAD digunakan untuk membiayai pembangunan dan penyelenggaraan pemerintah di daerah, sehingga meningkatnya PAD yang diterima Pemerintah Daerah berpengaruh terhadap meningkatnya pembangunan perekonomian daerah.

\section{METODOLOGI}

Penelitian ini terdiri atas dua variabel yang saling berkaitan yakni variabel bebas (independent variable) dan variabel terikat (dependent variable).Variabel bebas dalam penelitian ini adalah kontribusi penerimaan pendapatan sektor pariwisata yang meliputi pajak hotel, pajak restoran, dan pajak hiburan. Variabel terikat dalam penelitian ini adalah Pendapatan Asli Daerah (PAD).Penelitian ini bertujuan untuk mengetahui pengaruh kontribusi penerimaan pajak dari sektor pariwisata yang meliputi pajak hotel, pajak restoran, dan pajak hiburan.(variabel independent) terhadap Pendapatan Asli Daerah (variabel dependent) Kota Bandung.

\section{Metode yang Digunakan}

Dalam penelitian ini, penulis menggunakan metode jenis penelitian deskriptif dan verifikatif.Deskriptif yaitu dengan membuat deskripsi, gambaran atau lukisan secara sistematis, faktual dan akurat mengenai fakta-fakta, sifat-sifat serta hubungan antara fenomena yang diselidiki.Sedangkan verifikatif ingin menguji kebenaran dari suatu hipotesis yang dilaksanakan melalui pengumpulan data di lapangan guna menjelaskan pengaruh variabel ke variabel lainnya. 


\section{Sumber Data}

Sumber data yang digunakan adalah data sekunder yaitu data yang dikumpulkan oleh lembaga pengumpul data dan dipublikasikan kepada masyarakat pengguna data. Data yang digunakan dalam penelitian ini berupa laporan realisasi pendapatan dan belanja daerah khususnya penerimaan sektor pariwisata yang meliputi pajak hotel, pajak restoran, dan pajak hiburan periode 2011-2015 Kota Bandung dan menghitung pengaruh melalui uji parsial atau uji t dengan software SPSS Versi 24.0 dan Microsoft Excel 2015.

\section{Teknik Pengumpulan Data}

Adapun teknik pengumpulan data yang dilakukan dalam penelitian ini adalah sebagai berikut:

1. Penelitian kepustakaan (Library Research). Dilakukan dengan membaca referensi, buku, / literatur yang ada hubungannya dengan masalah penelitian.

2. Wawancara, Dilakukan berupa wawancara tidak terstruktur, yaitu wawancara bebas dimana peneliti tidak menggunakan pedoman wawancara yang telah tersusun secara sistematis dan lengkap untuk pengumpulan datanya dengan tujuan untuk mendapatkan informasi awal tentang berbagai isu atau permasalahan yang ada pada obyek sehingga peneliti dapat menentukan secara pasti permasalahan yang harus diteliti

3. Dokumentasi perusahaan, yaitu teknik pengumpulan data yang diperoleh melalui situs resmi Dinas Pelayanan Pajak Kota Bandung.

Tabel 3.

Operasionalisasi Variabel

\begin{tabular}{|c|c|c|c|c|c|}
\hline No & Variabel & Konsep & Dimensi & Indikator & Skala \\
\hline 1. & $\begin{array}{l}\text { Kontribusi } \\
\text { penerimaan } \\
\text { pajak dari } \\
\text { sektor } \\
\text { pariwisata }(\mathrm{X})\end{array}$ & $\begin{array}{l}\text { Kontribusi } \\
\text { penerimaan } \\
\text { pajak dari } \\
\text { sektor } \\
\text { pariwisata yang } \\
\text { meliputi pajak } \\
\text { hotel, pajak } \\
\text { restoran, dan } \\
\text { pajak hiburan. } \\
\text { (Perda No.20 } \\
\text { Tahun 2011 } \\
\text { tentang Pajak } \\
\text { Daerah Kota } \\
\text { Bandung). }\end{array}$ & $\begin{array}{l}\text { 1. Pajak hotel } \\
\text { 2. Pajak restoran } \\
\text { 3. Pajak hiburan } \\
\text { (Peraturan Daerah } \\
\text { Kota Bandung } \\
\text { No. } 20 \text { Tahun } \\
\text { 2011 tentang } \\
\text { Pajak Daerah Kota } \\
\text { Bandung) }\end{array}$ & $\begin{array}{l}\text { 1. Dokumen laporan } \\
\text { pajak hotel tahun } \\
\text { 2011-2015 } \\
\text { 2. Dokumen laporan } \\
\text { pajak restoran } \\
\text { tahun 2011-2015 } \\
\begin{array}{l}\text { 3. Dokumen laporan } \\
\text { pajak hiburan } \\
\text { tahun 2011-2015 }\end{array}\end{array}$ & Rasio \\
\hline
\end{tabular}




\begin{tabular}{|c|c|c|c|c|c|}
\hline 2. & $\begin{array}{l}\text { Pendapatan } \\
\text { Asli Daerah } \\
\text { (PAD) (Y) }\end{array}$ & $\begin{array}{l}\text { Penerimaan } \\
\text { yang diperoleh } \\
\text { daerah dari } \\
\text { sumber- } \\
\text { sumber dalam } \\
\text { wilayahnya } \\
\text { sendiri yang } \\
\text { dipungut } \\
\text { berdasarkan } \\
\text { peraturan } \\
\text { daerah, } \\
\text { sesuai dengan } \\
\text { peraturan } \\
\text { perundang- } \\
\text { undangan } \\
\text { yang berlaku, } \\
\text { (Pasal 157 UU } \\
\text { No 32 Tahun } \\
\text { 2004 tentang } \\
\text { Pemerintahan } \\
\text { Daerah). }\end{array}$ & $\begin{array}{l}\text { 1. Pajak Daerah } \\
\text { 2. Retribusi Daerah } \\
\text { 3. Hasil } \\
\text { Pengelolaan } \\
\text { Kekayaan } \\
\text { Daerah yang } \\
\text { Dipisahkan } \\
\text { 4. Lain-lain } \\
\text { Pendapatan yang } \\
\text { Sah } \\
\\
\text { (UU No } 32 \text { Tahun } \\
\text { 2004 tentang } \\
\text { Pemerintahan } \\
\text { Daerah) }\end{array}$ & $\begin{array}{l}\text { 1. Dokumen laporan } \\
\text { keuangan pajak } \\
\text { daerah tahun } \\
\text { 2011-2015 } \\
\text { 2. Dokumen laporan } \\
\text { retribusi daerah } \\
\text { tahun 2011-2015 } \\
\text { 3. Dokumen laporan } \\
\text { hasil pengelolaan } \\
\text { kekayaan daerah } \\
\text { yang dipisahkan } \\
\text { tahun 2011-2015 } \\
\text { 4. Dokumen } \\
\text { laporan lain-lain } \\
\text { pendapatan yang } \\
\text { sah tahun 2011- } \\
\text { 2015 }\end{array}$ & Rasio \\
\hline
\end{tabular}

\section{Rancangan Analisis Data}

Teknikanalisis data yang digunakanadalah TeknikAnalisis Kuantitatif, yaitu mengolah data dalam bentuk angka atau data dalam bentuk kualitatif yang diangkakan.Penelitian ini membandingkan variabel bebas yaitu kontribusi penerimaan pendapatansektor pariwisata yang meliputi pajak hotel, pajak restoran, dan pajak hiburanterhadap Pendapatan Asli Daerah (PAD) Kota Bandung sebagai variabel terikat.

Adapun alat analisis data yang digunakan dalam penelitian ini adalah Analisis Regresi Berganda.Purwanto (2011:188) menyatakan bahwa model regresi berganda merupakan perkembangan dari model regresi sederhana. Model regresi berganda dikembangkan untuk melakukan estimasi/prediksi nilai variabel dependen (Y) dengan menggunakan lebih dari satu variabel independen $\left(\mathrm{X}_{1}, \mathrm{X}_{2}, \mathrm{X}_{3}, \mathrm{dst}\right)$. Analisis regresi linear berganda digunakan untuk menguji adanya pengaruh antara kontribusi penerimaan pendapatansektor pariwisata yang meliputi pajak hotel, pajak restoran, dan pajak hiburansebagai variabel bebas yaitu $\left(\mathrm{X}_{1}, \mathrm{X}_{2}, \mathrm{X}_{3}\right)$ terhadap Pendapatan Asli Daerah (PAD) sebagai variabel terikat (Y).

Perhitungan analisis regresi linear berganda menurut Sugiyono (2014:192) dapat dirumuskan sebagai berikut: $\mathbf{Y}=\mathbf{a}+\mathbf{b}_{1} \mathbf{X}_{1}+\mathbf{b}_{2} \mathbf{X}_{2}+\mathbf{b}_{3} \mathbf{X}_{3}$

Keterangan: $\mathrm{Y}=$ Variabel Dependen (Pendapatan Asli Daerah)

$$
\begin{aligned}
& X_{1}=\text { Variabel Independen } X_{1} \text { (Pajak hotel) } \\
& X_{2}=\text { Variabel Independen } X_{2} \text { (Pajak restoran) }
\end{aligned}
$$




$$
\begin{array}{ll}
\mathrm{X}_{3} & =\text { Variabel Independen } \mathrm{X}_{3} \text { (Pajak hiburan) } \\
\mathrm{a} & =\text { Konstanta } \\
\mathrm{b}_{1} \mathrm{~b}_{2} \mathrm{~b}_{3} & =\text { Parameter yang mencerminkan variabel koefisien regresi }
\end{array}
$$

Dalam penelitian ini terdapat tiga variabel bebas, yaitu pajak hotel, pajak restoran, dan pajak hiburan sehingga dapat diketahui hubungan secara bersama-sama keterkaitan variabel dengan Pendapatan Asli Daerah (PAD). Untuk mengetahui signifikansi regresi linear berganda maka dapat dilakukan pengujian hipotesis dengan cara berikut:

\section{Kriteria sifnifikasi regresi hubungan $\mathrm{X}_{1}, \mathrm{X}_{2}, \mathrm{X}_{3}$ dengan $\mathrm{Y}$ :}

Dikatakan signifikan apabila nilai probabiliti Sig $<0,05$

Dikatakan tidak signifikan apabila nilai probabiliti Sig $>0,05$.

Dengan menggunakan teknik analisis regresi linear berganda akan dapat diketahui tingkat hubungan dari masing-masing variabel bebas dengan variabel terikat, yaitu tingkat hubungan pajak hotel, pajak restoran, dan pajak hiburandengan Pendapatan Asli Daerah (PAD) Kota Bandung.

\section{Koefisien Determinasi}

Koefisien determinasi ( $\mathrm{R}^{2}$ ) merupakan proporsi variabilitas dalam suatu data yang dihitung didasarkan pada model statistik (Sugiyono, 2012:75). Berguna untuk mengetahui adanya hubungan variabel independen $\mathrm{X}$ terhadap variabel dependen $\mathrm{Y}$. Pengujian $\mathrm{R}^{2}$ digunakan untuk mengukur proporsi atau persentase sumbangan variabel independen yang diteliti terhadap variasi naik turunnya variabel dependen. $\mathrm{R}^{2}$ ini mengukur seberapa besar kesamaan variabel yang akan diteliti yang berkisar antara 0 sampai $1(0 \leq \mathrm{R} 2 \leq 1)$.

Apabila $=0$ :Tidak adanya pengaruh variabel bebas terhadap variabel terikat Apabila $<0$ :Pengaruh variabel bebas semakin kecil terhadap variabel terikat Apabila $>0$ : Pengaruh variabel bebassemakin besar terhadap variabel terikat Dinyatakan dalam persentase dengan rumus sebagai berikut :

$$
d=r^{2} X 100 \%
$$

\section{Keterangan :}

$\mathrm{d}=$ Koefisien Determinasi

$\mathrm{r}=$ Koefisien Korelasi

Koefisien determinasi memiliki persentase $100 \%$. Apabila tidak $100 \%$ maka nilai sisa dari merupakan faktor lain yang mempengaruhi variabel terikat. 
Secara statistik untuk mengetahui seberapa besar kontribusi penerimaan pendapatansektor pariwisata yang meliputi pajak hotel $\left(\mathrm{X}_{1}\right)$, pajak restoran $\left(\mathrm{X}_{2}\right)$, dan pajak hiburan $\mathrm{X}_{3}$ ) terhadap Pendapatan Asli Daerah (Y) digunakan uji hipotesis yang terdiri dari koefisien determinasi, uji t, dan uji F statistik.

Hipotesa:

1. Ho ditolak, Ha diterima : $-\mathrm{t}_{\text {tabel }}>-\mathrm{t}_{\text {hitung }}$ atau $\mathrm{t}_{\text {hitung }}>\mathrm{t}_{\text {tabel }}:$ Terdapat pengaruh yang signifikan antara Pajak Hotel terhadap Pendapatan Asli Daerah (PAD) Kota Bandung.

2. Ho diterima, Ha ditolak : $-\mathrm{t}_{\text {tabel }}<-\mathrm{t}_{\text {hitung }}$ atau $\mathrm{t}_{\text {hitung }}<\mathrm{t}_{\text {tabel }}$ : Tidak terdapat pengaruh yang signifikan antara Pajak Hotel terhadap Pendapatan Asli Daerah (PAD)

Pengujian hipotesis dilakukan dengan regresi linier berganda dengan tingkat signifikansinya $5 \%$.

Pengujian Parsial (Uji t).Digunakan untuk mengetahui apakah variabel independen mempunyai pengaruh yang signifikan terhadap variabel dependen.

Pengujian Simultan ( Uji F ). Digunakan untuk menguji tingkat signifikansi koefisien regresi variabel independen secara serempak terhadap variabel dependen

\section{HASIL DAN PEMBAHASAN}

\section{Perkembangan Penerimaan Pendapatan Sektor Pariwisata Kota Bandung}

\section{Pajak Hotel}

Menurut Peraturan Daerah Kota Bandung No. 20 Tahun 2011, pengertian hotel menurut adalah fasilitas penyedia jasa penginapan atau peristirahatan termasuk jasa terkait lainnya dengan dipungut bayaran, yang mencakup juga motel, losmen, gubuk pariwisata, wisma pariwisata, pesanggrahan, rumah penginapan dan sejenisnya, serta rumah kos dengan jumlah kamar lebih dari angka 10 (sepuluh). Berikut ini tabel persentase pajak hotel Kota Bandung tahun 2011-2015:

Tabel 4.

Persentase Pajak Hotel Kota BandungTahun Anggaran 2011-2015

\begin{tabular}{|c|c|r|r|r|}
\hline Tahun Anggaran & $\begin{array}{c}\text { Target Pajak } \\
\text { Hotel }\end{array}$ & $\begin{array}{c}\text { Realisasi Pajak } \\
\text { Hotel }\end{array}$ & $\begin{array}{c}\text { Persentase Efektivi- } \\
\text { tas (\%) }\end{array}$ & Growth (\%) \\
\hline 2011 & 92.000 .000 .000 & 112.007 .259 .932 & 171.75 & 0 \\
\hline 2012 & 131.000 .000 .000 & 142.737 .317 .105 & 108,96 & 27,43 \\
\hline 2013 & 148.000 .000 .000 & 177.490 .303 .830 & 119,93 & 24,35 \\
\hline 2014 & 202.850 .000 .000 & 204.152 .062 .826 & 100,64 & 15,02 \\
\hline 2015 & 260.000 .000 .000 & 215.285 .361 .236 & 52,8 & 5,45 \\
\hline Jumlah & 833.850 .000 .000 & 851.672 .304 .929 & 106,82 & \\
\hline & & Rata-Rata & & \\
\hline
\end{tabular}

Sumber: Diolah Kembali 
Dari tabel di atas dapat disimpulkan bahwa realisasi penerimaan pajak hotel di Kota Bandung dari tahun 2011 sampai dengan 2015 mengalami kenaikan dengan persentase efektivitas dan tingkat pertumbuhan yang menurun setiap tahunnya. Walaupun mengalami penurunan setiap tahunnya tetapi persentase efektivitas dan tingkat pertumbuhan pajak hotel tetap bergerak positif, artinya dari tahun ke tahun realisasi penerimaan pajak hotel mengalami peningkatan walaupun persentase efektifitas dan pertumbuhan tidak mengalami kenaikan setiap tahunnya.Rata-rata efektivitas penerimaan pajak hotel yang lebih dari $100 \%$ dengan rata-rata sebesar $106,82 \%$ setiap tahunnya. Hal ini menunjukkan bahwa realisasi pajak hotel rata-rata lebih besar daripada target yang direncanakan atau yang ditetapkan meskipun pada tahun 2015 realisasi pajak hotel tidak sesuai dengan target. Hal ini disebabkan oleh terjadinya akibat penggelapan pajak oleh sejumlah pengusaha hotel dan adanya kebijakan Pemerintah Pusat yang melarang penggunaan hotel dalam kegiatan pemerintahan.

Tingkat penerimaan Pajak Hotel di Kota Bandung dihitung dengan membandingkan antara realisasi penerimaan Pajak Hotel dengan target Pajak Hotel dengan rumus

Realisasi Penerimaan Pajak Hotel X $100 \%$

Efektivitas : $\quad$ Target Penerimaan Pajak Hotel

Apabila perhitungan efektivitas Pajak Hotel menghasilkan persentase melebihi 100\%, maka Pajak Hotel semakin efektif sehingga kinerja pemungutan atas Pajak Hotel di Kota Bandung semakin baik karena yang dipertimbangkan dalam menentukan efektivitas hanya pencapaian target. Adapun grafik dari target dan realisasi penerimaan Pajak Hotel Kota Bandung sebagai berikut :

\section{Gambar 1. Grafik Target dan Realisasi Pajak Hotel}

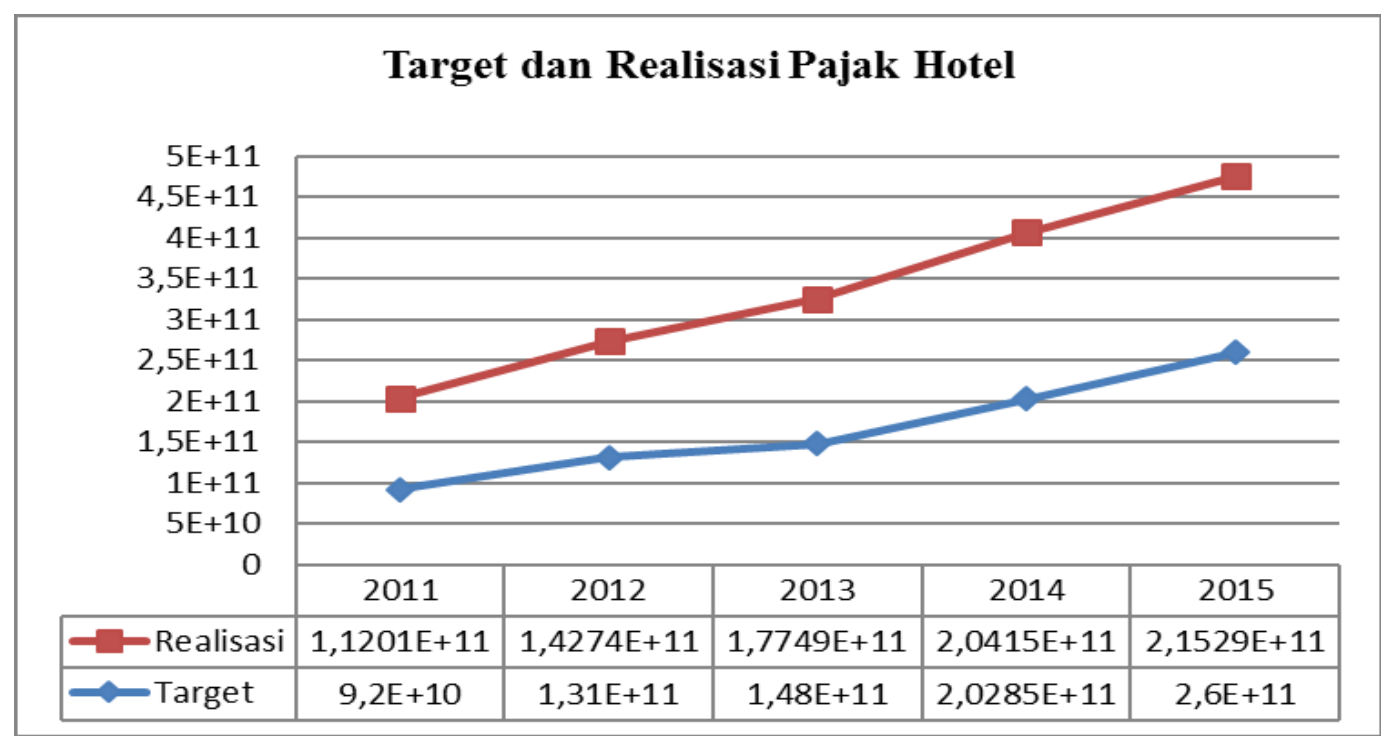

Sumber: Diolah Kembali 


\section{Pajak Restoran}

Pengertian restoran menurut Peraturan Daerah Kota Bandung No. 20 Tahun 2011 adalah fasilitas penyedia makanan dan atau minuman dengan dipungut bayaran, yang mencakup juga rumah makan, kafetaria, kantin, warung, bar, dan sejenisnya termasuk jasa boga/catering. Berikut ini tabel persentase pajak restoran di Kota Bandung tahun 2011-2015

Tabel 5.

Persentase Pajak Restoran Kota Bandung Tahun Anggaran 2011-2015

\begin{tabular}{|c|c|c|c|c|}
\hline Tahun Anggaran & Target Pajak Restoran & $\begin{array}{c}\text { Realisasi Pajak } \\
\text { Restoran }\end{array}$ & $\begin{array}{c}\text { Persentase Efektivitas } \\
(\%)\end{array}$ & $\begin{array}{c}\text { Growth } \\
(\%)\end{array}$ \\
\hline 2011 & 75.000 .000 .000 & 83.562 .707 .583 & 111,42 & 0 \\
\hline 2012 & 88.500 .000 .000 & 97.356 .787 .188 & 110,01 & 16,51 \\
\hline 2013 & 102.000 .000 .000 & 118.700 .322 .856 & 116,37 & 21,92 \\
\hline 2014 & 140.000 .000 .000 & 142.399 .711 .300 & 101,71 & 19,97 \\
\hline 2015 & 170.000 .000 .000 & 181.401 .845 .809 & 106,71 & 27,39 \\
\hline Jumlah & 575.500 .000 .000 & 623.421 .354 .756 & 546,22 & \\
\hline & & Rata-Rata & 109,24 & \\
\hline
\end{tabular}

Sumber: Diolah Kembali

Dari tabel di atas dapat disimpulkan bahwa realisasi penerimaan pajak restorandi Kota Bandung pada tahun 2011 sampai dengan 2012 mengalami kenaikan dengan tingkat pertumbuhan sebesar 16.51\%, 21,92\%, 19,97\% dan 27,39,92\%. Di tahun 2014, pertumbuhan mengalami penurunan sebesar 1,95\% dari tahun sebelumnya. Walaupun demikian, di tahun 2015 pertumbuhannya mengalami peningkatan sebesar $7.42 \%$ jika dibandingkan dengan tahun sebelumnya. Meskipun naik turun setiap tahunnya tetapi persentase efektivitas dan tingkat pertumbuhan pajak restorantetap bergerak positif, artinya dari tahun ke tahun realisasi penerimaan Pajak Restoran Kota Bandung mengalami peningkatan walaupun persentase efektifitas dan pertumbuhan tidak mengalami kenaikan dan penurunan setiap tahunnya. Melihat rata-rata efektivitas penerimaan Pajak Restoran Kota Bandung yang lebih dari 100\% dengan rata-rata sebesar 109,24\% setiap tahunnya. Hal ini menunjukkan bahwa realisasi pajak restoran rata-rata lebih besar daripada target yang direncanakan atau yang ditetapkan meskipun pada tahun 2014 realisasi pajak restoran tidak sesuai dengan target.

Tingkat penerimaan pajak restoran di Kota Bandung dihitung dengan membandingkan antara realisasi penerimaan Pajak Restorandengan target Pajak Restorandengan rumus

Realisasi Penerimaan Pajak Restoran X 100 \%

Efektivitas : $\quad$ Target Penerimaan Pajak Restoran

Apabila perhitungan efektivitas Pajak Restoranmenghasilkan persentase melebihi 100\%, maka Pajak Restoran semakin efektif sehingga kinerja pemungutan atas Pajak Restoran di Kota Bandung semakin baik karena yang dipertimbangkan dalam menentu- 
kan efektivitas hanya pencapaian target. Adapun grafik dari target dan realisasi penerimaan Pajak Restoran Kota Bandung sebagai berikut:

Gambar 2. Grafik Target dan Realisasi Pajak Restoran

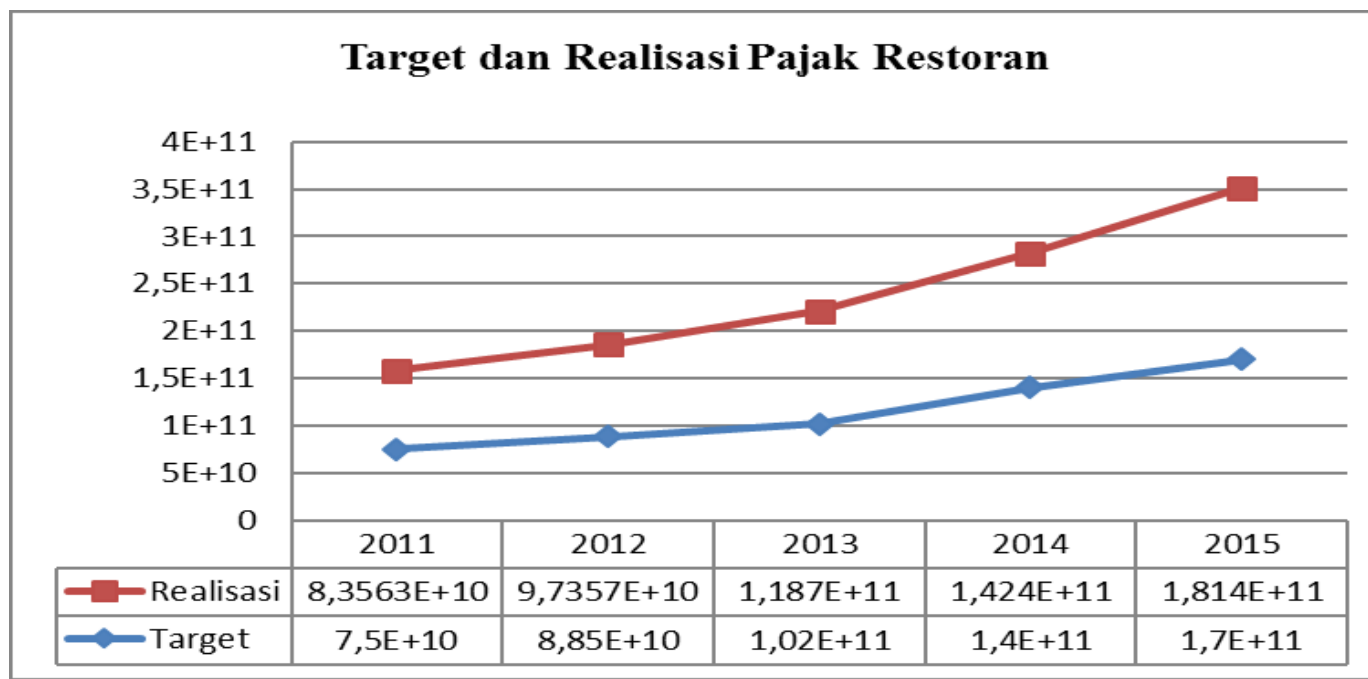

Sumber: Diolah Kembali

\section{Pajak Hiburan}

Menurut Peraturan Daerah Kota Bandung No. 20 Tahun 2011 adalah semua jenis tontonan, pertunjukan, permainan dan/atau keramaian yang dinikmati dengan dipungut bayaran.Berikut ini adalah tabel persentase pajak hiburandi Kota Bandung tahun 20112015:

Tabel 6.

Persentase Pajak Hiburan Kota BandungTahun Anggaran 2011-2015

\begin{tabular}{|c|c|c|c|c|}
\hline Tahun Anggaran & Target Pajak Hiburan & $\begin{array}{c}\text { Realisasi Pajak } \\
\text { Hiburan }\end{array}$ & $\begin{array}{c}\text { Persentase } \\
\text { Efektivitas (\%) }\end{array}$ & $\begin{array}{c}\text { Growth } \\
(\%)\end{array}$ \\
\hline 2011 & 28.000 .000 .000 & 31.223 .414 .896 & 111,51 & 0 \\
\hline 2012 & 33.000 .000 .000 & 34.553 .186 .144 & 104,71 & 10,66 \\
\hline 2013 & 35.500 .000 .000 & 37.767 .188 .531 & 106,39 & 9,3 \\
\hline 2014 & 45.000 .000 .000 & 40.730 .151 .211 & 90,51 & 7,85 \\
\hline 2015 & 60.000 .000 .000 & 50.429 .747 .411 & 84,05 & 23,81 \\
\hline Jumlah & 201.500 .000 .000 & 190.703 .688 .193 & 497,17 & \\
\hline & & Rata-Rata & 99,43 & \\
\hline
\end{tabular}

Sumber: Diolah Kembali

Dari tabel di atas dapat disimpulkan bahwa realisasi penerimaan pajak hiburan di Kota Bandung pada tahun 2011 sampai dengan 2015 mengalami kenaikan dengan tingkat pertumbuhan sebesar 10,66\%, 9,3\%,7,85\% dan 23,81\%. Dari tahun 2011 sampai tahun 
2014, pertumbuhan mengalami penurunan akan tetapi pada tahun 2015 pertumbuhannya mengalami peningkatan signifikan jika dibandingkan dengan tahun sebelumnya. Meskipun naik turun setiap tahunnya tetapipersentase efektivitas dan tingkat pertumbuhan pajak hiburan tetap bergerak positif, artinya dari tahun ke tahun realisasi penerimaan pajak hiburan mengalami peningkatan walaupun persentase efektifitas dan pertumbuhan tidak mengalami kenaikan dan penurunan setiap tahunnya.

Melihat rata-rata efektivitas penerimaan pajak hiburan di Kota Bandung lebih dari $100 \%$ dengan rata-rata sebesar 99,4\%3 setiap tahunnya. Hal ini menunjukkan bahwa realisasi Pajak Hiburan rata-rata lebih besar daripada target yang direncanakan atau yang ditetapkan meskipun pada tahun 2014dan 2015 realisasi Pajak Hiburan tidak sesuai dengan target. Hal ini disebabkan oleh adanya pembatasan jam operasional tempat hiburan, 9 WP menutup tempat usahanya dan 4 WPmenutup sementara tempat usahanya. Adapun tingkat penerimaan Pajak Hiburan di Kota Bandung dihitung dengan membandingkan antara realisasi penerimaan Pajak Hiburan dengan target Pajak Hiburan dengan rumus

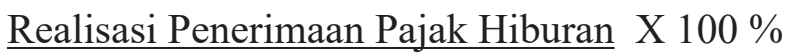

Efektivitas : Target Penerimaan Pajak Hiburan

Apabila perhitungan efektivitas pajak hiburan menghasilkan persentase melebihi $100 \%$, maka pajak hiburan semakin efektif sehingga kinerja pemungutan atas pajak hiburan di Kota Bandung semakin baik karena yang dipertimbangkan dalam menentukan efektivitas hanya pencapaian target.Adapun grafik dari target dan realisasi penerimaan pajak hiburan Kota Bandung sebagai berikut :

\section{Gambar 3.Grafik Target dan Realisasi Pajak Hiburan}

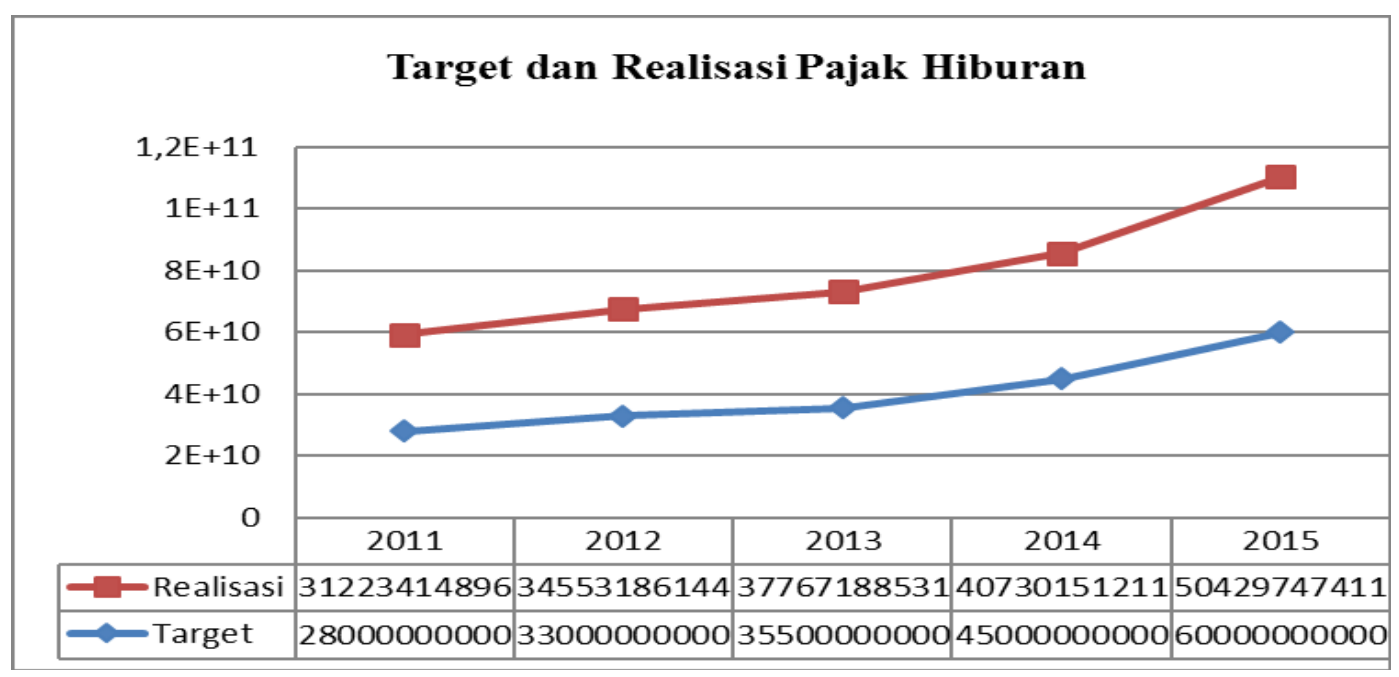

Sumber: Diolah Kembali

\section{Pendapatan Asli Daerah (PAD)}

Menurut UU No.33 Tahun 2004, Pendapatan Asli Daerah merupakan sumber penerimaan daerah asli yang digali di daerah tersebut untuk digunakan sebagai modal 
dasar pemerintah daerah dalam membiayai pembangunan dan usaha-usaha daerah untuk memperkecil ketergantungan dana dari pemerintah pusat. Pendapatan Asli Daerah terdiri dari Pajak Daerah, Retribusi Daerah, Hasil Pengelolaan Kekayaan Daerah yang Dipisahkan, dan Lain-Lain Pendapatan Daerah yang Sah. Berikut ini tabel persentase Pendapatan Sektor Pariwisata Kota Bandung tahun 2011-2015:

\section{Tabel 7.}

Persentase Pendapatan Sektor Pariwisata Kota Bandung Tahun Anggaran 2011-2015

\begin{tabular}{|c|c|c|c|c|}
\hline Tahun Anggaran & $\begin{array}{c}\text { Target Pendapatan Sektor } \\
\text { Pariwisata }\end{array}$ & $\begin{array}{c}\text { Realisasi Pendapatan Sektor } \\
\text { Pariwisata }\end{array}$ & $\begin{array}{c}\text { Persentase Efektivitas } \\
(\%)\end{array}$ & $\begin{array}{c}\text { Growth } \\
(\%)\end{array}$ \\
\hline 2011 & 195.000 .000 .000 & 226.793 .382 .411 & 116,3 & 0 \\
\hline 2012 & 252.500 .000 .000 & 274.642 .290 .437 & 108,77 & 21,1 \\
\hline 2013 & 285.500 .000 .000 & 333.957 .815 .217 & 116,97 & 21,6 \\
\hline 2014 & 387.850 .000 .000 & 387.281 .925 .337 & 99,85 & 15,97 \\
\hline 2015 & 490.000 .000 .000 & 447.116 .954 .456 & 84,05 & 15,45 \\
\hline Jumlah & 1.610 .850 .000 .000 & 1.669 .792 .367 .858 & 533,14 & \\
\hline & & Rata-Rata & 106,62 & \\
\hline
\end{tabular}

Sumber: Diolah Kembali

Dari tabel di atas dapat disimpulkan bahwa realisasi penerimaan pendapatan sektor pariwisata Kota Bandung pada tahun 2011 sampai dengan 2015 mengalami kenaikan dengan tingkat pertumbuhan sebesar 21,10\%, 21.60\%, 15.97\% dan 15,45\%. Dari tahun 2011 sampai tahun 2013, pertumbuhan mengalami kenaikan akan tetapi pada tahun 2014 sampai tahun 2015 pertumbuhannya mengalami penurunan jika dibandingkan dengan tahun sebelumnya. Meskipun naik turun fluktuatif setiap tahunnya, tetapi persentase efektivitas dan tingkat pertumbuhan pendapatan sektor pariwisatatetap bergerak positif, artinya dari tahun ke tahun realisasi penerimaanpendapatan sektor pariwisata mengalami peningkatan walaupun persentase efektifitas dan pertumbuhan mengalami kenaikan dan penurunan setiap tahunnya.

Melihat rata-rata efektivitas pendapatan sektor pariwisataKota Bandung yang lebih dari $100 \%$ dengan rata-rata sebesar $106,62 \%$ setiap tahunnya. Hal ini menunjukkan bahwa realisasi rata-rata lebih besar daripada target yang direncanakan atau yang ditetapkan meskipun pada tahun 2014dan 2015realisasipenerimaan pendapatan sektor pariwisatatidak sesuai dengan target. Hal ini disebabkan oleh penggelapan pajak oleh sejumlah pengusaha hotel, adanya kebijakan Pemerintah Pusat yang melarang penggunaan hotel dalam mengadakan rapat, adanya pembatasan jam operasional tempat hiburan, 9 WP menutup tempat usahanya dan 4 WP menutup sementara tempat usahan serta occupancy menurun membuat penerimaan pendapatan di sektor pariwisatamenurun di tahun 2014 dan 2015.

Tingkat penerimaan pendapatan sektor pariwisatadi Kota Bandung dihitung dengan membandingkan antara realisasi penerimaan pendapatan sektor pariwisatadengan target penerimaan pendapatan sektor pariwisatadengan rumus 


\section{Realisasi Penerimaan Pendapatan Sektor PariwisataX $100 \%$}

Efektivitas : Target Penerimaan Pendapatan Sektor Pariwisata

Apabilaperhitunganefektivitaspenerimaanpendapatansektorpariwisatamenghasilkan persentase melebihi $100 \%$, maka penerimaan pendapatan sektor pariwisatasemakin efektif sehingga kinerja penerimaan pendapatan sektor pariwisata yang terdiri atas pajak hotel, pajak restoran dan pajak hiburan di Kota Bandung semakin baik karena yang dipertimbangkan dalam menentukan efektivitas hanya pencapaian target. Adapun grafik dari target dan realisasi penerimaan pendapatan sektor pariwisatadi Kota Bandung sebagai berikut:

\section{Gambar 4.Grafik Target dan Realisasi Penerimaan Pendapatan}

\section{Sektor Pariwisata}

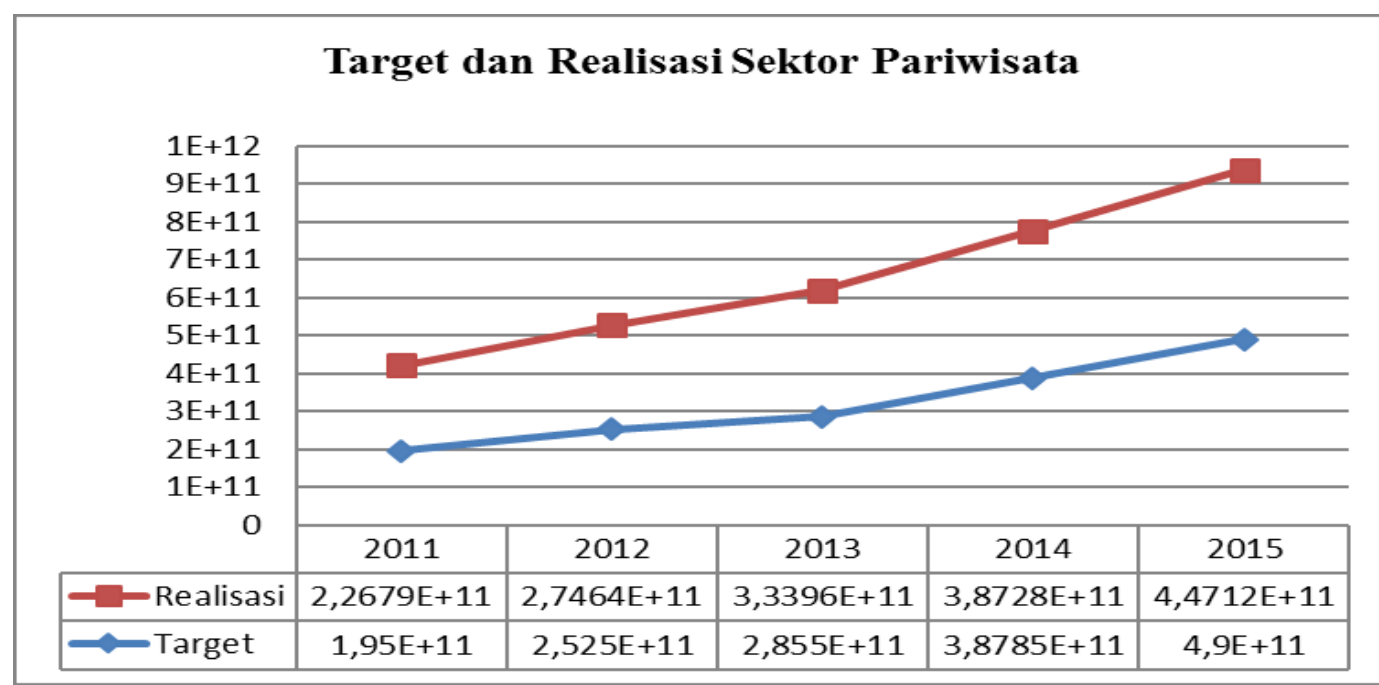

Sumber: Diolah Kembali

Berikut ini tabel persentase Pendapatan Asli Daerah (PAD) Kota Bandung tahun 2011-2015:

Tabel 8.

\section{Persentase Penerimaan Pendapatan Asli Daerah (PAD) Kota Bandung} Tahun 2011-2015

\begin{tabular}{|c|c|c|c|c|}
\hline $\begin{array}{c}\text { Tahun } \\
\text { Anggaran }\end{array}$ & $\begin{array}{c}\text { Target Pendapatan } \\
\text { Asli Daerah (PAD) }\end{array}$ & $\begin{array}{c}\text { Realisasi Pendapatan } \\
\text { Asli Daerah (PAD) }\end{array}$ & $\begin{array}{c}\text { Persentase } \\
\text { Efektivitas (\%) }\end{array}$ & $\begin{array}{c}\text { Growth } \\
(\%)\end{array}$ \\
\hline 2011 & 546.000 .000 .000 & 667.275 .019 .226 & 122,21 & 0 \\
\hline 2012 & 727.000 .000 .000 & 820.714 .860 .033 & 112,89 & 22,99 \\
\hline 2013 & 1.407 .759 .106 .133 & 1.442 .775 .238 .323 & 102,49 & 75,79 \\
\hline 2014 & 1.808 .509 .055 .075 & 1.716 .057 .298 .378 & 94,89 & 18,94 \\
\hline 2015 & 2.085 .795 .015 .103 & 1.962 .526 .167 .268 & 94,09 & 15,91 \\
\hline Jumlah & 6.575 .063 .176 .311 & 6.635 .822 .415 .960 & 526,57 & \\
\hline & & Rata-Rata & 105,31 & \\
\hline
\end{tabular}

Sumber: Diolah Kembali 
Dari tabel tersebut dapat disimpulkan bahwa realisasi penerimaan Pendapatan Asli Daerah (PAD) di Kota Bandung pada tahun 2011 sampai dengan 2015 mengalami kenaikan dengan tingkat pertumbuhan sebesar 22,99\%, 75,79\%, 18,94\% dan 15,91\%. Dari tahun 2011 sampai tahun 2013, pertumbuhan mengalami kenaikan akan tetapi mulai tahun 2014 sampai tahun 2015 pertumbuhannya mengalami penurunan. Di tahun 2014, pertumbuhan mengalami penurunan signifikan sebesar 56,65\% jika dibandingkan dengan tahun sebelumnya. Sedangkan di tahun 2015, Pendapatan Asli Daerah (PAD) Kota Bandung mengalami penurunan sebesar 3,03\% jika dibandingkan tahun sebelumnya. Meskipun naik turun fluktuatif setiap tahunnya, tetapi persentase efektivitas dan tingkat pertumbuhan Pendapatan Asli Daerah (PAD)tetap bergerak positif, artinya dari tahun ke tahun realisasi penerimaan Pendapatan Asli Daerah (PAD)Kota Bandung mengalami peningkatan walaupun persentase efektifitas dan pertumbuhan mengalami kenaikan dan penurunan setiap tahunnya.

Melihat rata-rata efektivitas penerimaan Pendapatan Asli Daerah (PAD) Kota Bandung yang lebih dari 100\% dengan rata-rata sebesar 105,31\%\% setiap tahunnya. Hal ini menunjukkan bahwa realisasi rata-rata lebih besar daripada target yang direncanakan atau yang ditetapkan meskipun pada tahun 2014dan 2015 realisasi Pendapatan Asli Daerah (PAD) Kota Bandung tidak sesuai dengan target. Hal ini disebabkan oleh penggelapan pajak oleh sejumlah pengusaha hotel, adanya kebijakan Pemerintah Pusat yang melarang penggunaan hotel dalam mengadakan rapat, adanya pembatasan jam operasional tempat hiburan, 9 WP menutup tempat usahanya dan 4 WP menutup sementara tempat usahanyaserta occupancy menurun membuat pendapatan di sektor Pendapatan Asli Daerah (PAD) Kota Bandung menurun di tahun 2014 dan 2015.

Tingkat penerimaan Pendapatan Asli Daerah (PAD) di Kota Bandung dihitung dengan membandingkan antara realisasi penerimaan Pendapatan Asli Daerah (PAD) dengan target Pendapatan Asli Daerah (PAD) dengan rumus

\section{Realisasi Penerimaan Pendapatan Asli Daerah (PAD)X $100 \%$}

Efektivitas : $\quad$ Target Penerimaan Pendapatan Asli Daerah (PAD)

Apabila perhitungan efektivitas Pendapatan Asli Daerah (PAD) menghasilkan persentase melebihi 100\%, maka Pendapatan Pendapatan Asli Daerah (PAD) semakin efektif sehingga kinerja pemungutan atas Pendapatan Asli Daerah (PAD).

Berdasarkan Undang-undang No. 32 Tahun 2004 pasal 157 tentang Pemerintah Daerah, sumber pendapatan tetap yang digunakan untuk membiayai berbagai kegiatan daerah otonom terdiri dari Pendapatan Asli Daerah, Dana Perimbangan dan Lain-lain Pendapatan yang Sah. Sumber Pendapatan Asli Daerah merupakan sumber keuangan daerah yang digali dari dalam wilayah daerah yang bersangkutan.Proporsi pendapatan asli daerah dalam seluruh penerimaan daerah masih rendah bila dibandingkan dengan penerimaan dari bantuan pemerintah pusat. Demikian pula alternatif-alternatif untuk memaksimalkan pendapatan asli daerah telah di pertimbangkan oleh pemerintah kota. Adapun grafik dari target dan realisasi Pendapatan Sektor Pariwisatasebagai berikut: 
Gambar 5.Grafik Target dan Realisasi Pendapatan Asli Daerah (PAD) Kota Bandung

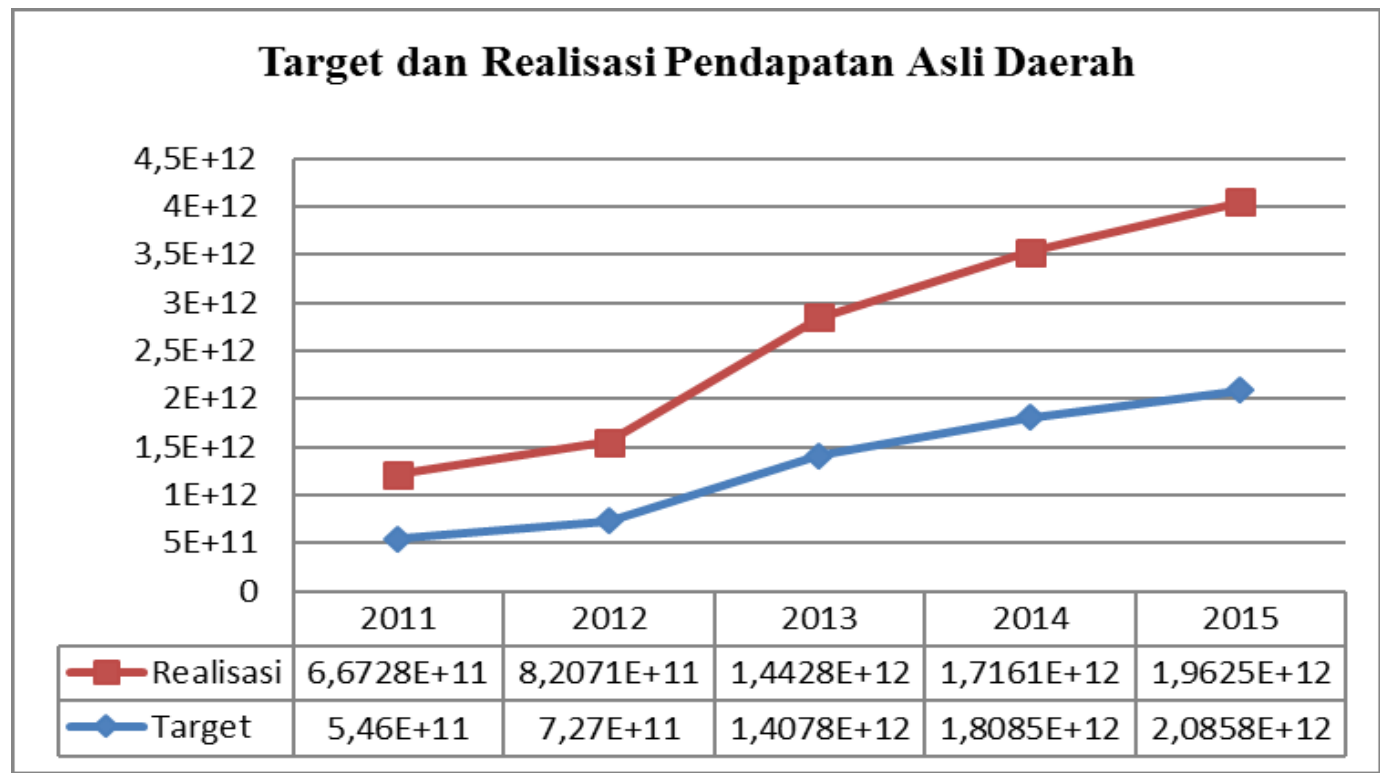

Sumber: Diolah Kembali

\section{Pengujian Hipotesis}

Pada dasarnya analisa kontribusi penerimaanpendapatan sektor pariwisata yang meliputi pajak hotel, pajak restoran, dan pajak hiburan terhadap Pendapatan Asli Daerah untuk menjawab hipotesis yang ada. Analisa yang dilakukan yaitu sebagai berikut:

\section{Kontribusi Penerimaan Pendapatan Sektor Pariwisata Terhadap Pendapatan Asli Daerah (PAD) Kota Bandung}

Sektor pariwisata memiliki peran penting atas Pendapatan Asli Daerah Kota Bandung.Adapun dibawah ini terdapat realisasi penerimaan pendapatan sektor pariwisata dan Pendapatan Asli Daerah (PAD) Kota Bandung periode 2011-2015. Untuk mengetahui kontribusi penerimaan pendapatan sektor pariwisata terhadap Pendapatan Asli Daerah Kota Bandung, dapat dilihat pada tabel berikut ini:

Tabel 10.

Realisasi Penerimaan Pendapatan Sektor Pariwisata dan Pendapatan Asli Daerah (PAD) Kota Bandung Tahun 2011-2015

\begin{tabular}{|c|c|c|}
\hline Tahun Anggaran & $\begin{array}{c}\text { Penerimaan Pendapatan Sektor } \\
\text { Pariwisata }\end{array}$ & $\begin{array}{c}\text { Pendapatan Asli Daerah } \\
\text { (PAD) }\end{array}$ \\
\hline 2011 & 226.793 .382 .411 & 667.275 .019 .226 \\
\hline 2012 & 274.642 .290 .437 & 820.714 .860 .033 \\
\hline 2013 & 333.957 .815 .217 & 1.442 .775 .238 .323 \\
\hline
\end{tabular}




\begin{tabular}{|c|c|c|}
\hline 2014 & 387.281 .925 .337 & 1.716 .057 .298 .378 \\
\hline 2015 & 447.116 .954 .456 & 1.962 .526 .167 .268 \\
\hline Jumlah & 1.669 .792 .367 .858 & 6.609 .350 .583 .228 \\
\hline
\end{tabular}

Sumber: Diolah Kembali

Dari tabel di atas dapat disimpulkan bahwa realisasi penerimaan pendapatan sektor pariwisata dan Pendapatan Asli Daerah (PAD) dari tahun ke tahun terus meningkat dengan nilai tertinggi di tahun 2015.Untuk mengetahui growth (tingkat pertumbuhan) penerimaan pendapatan sektor pariwisata dan Pendapatan Asli Daerah (PAD) Kota Bandung tahun 2011-2015 dapat dilihat pada tabel berikut ini :

Tabel 10.

Growth Antara Penerimaan Pendapatan Sektor Pariwisata dan Pendapatan Asli Daerah (PAD) Kota Bandung Tahun Anggaran 2011-2015

\begin{tabular}{|c|c|c|}
\hline Tahun Anggaran & $\begin{array}{c}\text { Growth Penerimaan Pendapatan } \\
\text { Sektor Pariwisata }\end{array}$ & $\begin{array}{c}\text { Growth Pendapatan Asli Daer- } \\
\text { ah (PAD) Kota Bandung }\end{array}$ \\
\hline 2011 & 0 & 0 \\
\hline 2012 & 21,1 & 22,99 \\
\hline 2013 & 21,6 & 75,79 \\
\hline 2014 & 15,97 & 18,94 \\
\hline 2015 & 15,4 & 15,91 \\
\hline
\end{tabular}

Sumber: Diolah Kembali

Penerimaan Pendapatan Sektor Pariwisata dan Pendapatan Asli Daerah (PAD) Kota Bandung Tahun 2011-2015

Hasil output SPSS Versi 24.0untuk analisis regresi linier berganda antara Penerimaan Pendapatan Sektor Pajakterhadap Pendapatan Asli Daerah (PAD) tergambar sebagai berikut:

Tabel 11.

Analisis Regresi Linier Berganda Pendapatan Sektor Pariwisata (pajak hotel, pajak restoran, dan pajak hiburan terhadap Pendapatan Asli Daerah Coefficients

\begin{tabular}{|c|c|c|c|c|c|}
\hline \multirow{2}{*}{ Model } & \multicolumn{2}{|c|}{ Unstandardized Coefficients } & \multirow{2}{*}{$\begin{array}{c}\text { Standardized } \\
\text { Coefficients } \\
\text { Beta }\end{array}$} & \multirow{2}{*}{$\mathbf{T}$} & \multirow{2}{*}{ Sig. } \\
\hline & B & Std. Error & & & \\
\hline 1. (Constant) & $7,293+\mathrm{E} 10$ & $1,751+\mathrm{E} 12$ & &, 041 & ,974 \\
\hline Pajak Hotel & 7,570 & 6,513 &, 579 & 1,162 & 452 \\
\hline Pajak Restoran & 15,452 & 23,792 & 1,067 & ,649 & ,633 \\
\hline Pajak Hiburan & $-50,501$ & 100,105 &,- 660 &,- 504 & ,703 \\
\hline
\end{tabular}

a. Dependent Variable: PAD

Sumber: Diolah Kembali 
Berdasarkan tabel diatas disimpulkan bahwa nilai konstanta (a) sebesar 7,293 dengan koefisien regresi (b1) sebesar 7,570, (b2) sebesar 15,452, dan (b3) sebesar -50,501. Sehingga persamaan regresi linier berganda dari pengaruh pajak hotel, pajak restoran, dan pajak hiburan terhadap Pendapatan Asli Daerahadalah sebagai berikut:

$$
\begin{aligned}
& \text { Persamaan Regresi Linier Berganda } X_{1}, X_{2}, X_{3} \text { terhadap } Y \\
& Y Y=7,293+7,570 X 1+15,452 X 2-50,501 X 3
\end{aligned}
$$

Dari persamaan diatas disimpulkan bahwa variabel independen dianggap konstan maka perubahan dalam Pendapatan Asli Daerah (PAD) adalah sebesar 7,293.Jika terjadi peningkatan jumlah pajak hotel $\left(\mathrm{X}_{1}\right)$ sebesar $1 \%$ maka mengakibatkan nilai Pendapatan Asli Daerah (PAD) bertambah sebesar 7,570. Sebaliknya, pajak hotel $\left(\mathrm{X}_{1}\right)$ berkurang 1\% maka nilai Pendapatan Asli Daerah akan mengalami penurunan sebesar 7,570. Hal yang sama terjadi pada pajak restoran, dan pajak hiburan $\left(\mathrm{X}_{2}\right.$, dan $\mathrm{X}$.)

Analisis koefisien determinasi digunakan mengukur besarnya kontribusi variabel independen (X) terhadap variabel dependen (Y). Hasil Output SPSS Versi 24.0 untuk analisis koefisien determinasi tergambar dalam tabel dibawah ini:

Tabel 12.

Koefisien Determinasi Penerimaan Pendapatan Sektor Pariwisata (X) Terhadap Pendapatan Asli Daerah (Y)

\begin{tabular}{|c|c|c|c|c|}
\hline \multicolumn{5}{|c|}{ Model Summary } \\
\hline Model & R & R Square & Adjusted R Square & Std. Error of the Estimate \\
\hline 1 &, $991 \mathrm{a}$ &, 983 &, 932 & $1,466 \mathrm{E}+11$ \\
\hline
\end{tabular}

Sumber: Diolah Kembali

Berdasarkan perhitungan diatas, maka $R$ Square sebesar 0,983. Sehingga nilai koefisien determinasi $\quad \mathrm{d}=0,983 \times 100=98,3 \%$

Dari perhitungan diketahui koefisien determinasi (r2) h sebesar 98,3\%. Menunjukkan bahwa pengaruh antara variabel pajak hotel, pajak restoran, dan pajak hiburan terhadap variabel Pendapatan Asli Daerah adalah sebesar 98,3\%. Sedangkan sisanya sebesar 1,7\% dipengaruhi oleh variabel lain yang tidak diteliti dalam penelitian ini.

Uji t digunakan untuk mengetahui apakah Pendapatan Sektor Pariwisata(independen) secara parsial mempunyai pengaruh signifikan terhadap variabel Pendapatan Asli Daerah (dependen). Adapun hasil Uji t dapat terlihat dalam tabel berikut ini : 
Tabel 13.

Uji t Pajak Hotel terhadap Pendapatan Asli Daerah

\section{Coefficients}

\begin{tabular}{|c|c|c|c|c|c|}
\hline \multirow{2}{*}{ Model } & \multicolumn{2}{|c|}{ Unstandardized Coefficients } & \multirow{2}{*}{$\begin{array}{l}\text { Standardized } \\
\text { Coefficients } \\
\text { Beta }\end{array}$} & \multirow{2}{*}{$\mathbf{T}$} & \multirow{2}{*}{ Sig. } \\
\hline & B & Std. Error & & & \\
\hline 1. (Constant) & $-8,711 \mathrm{E}+11$ & $2,254 \mathrm{E}+11$ & & $-3,863$ & 031 \\
\hline Pajak Hotel & 12,875 & 1,291 & .985 & 9,970 & .082 \\
\hline
\end{tabular}

a. Dependent Variable: PAD

Sumber: Diolah Kembali

Berdasarkan perhitungan diatas, maka diperoleh Thitung untuk variabel $\left(\mathrm{X}_{1}\right)$ sebesar 9,970.Dengan tingkat signifikansi sebesar 5\% $(0,05)$ diperoleh ttabel 12,706.sehingga thitung $<$ ttabel $=9,970<12,706$. Tingkat signifikansinya menunjukkan nilai signifikansi besar dari 0,05 yaitu 0,082 >0,05. Dengan demikian, Ho diterima atau Ha ditolak yang artinya tidak terdapat pengaruh yang signifikan antara variabel Pajak Hotel terhadap variabel Pendapatan Asli Daerah Kota Bandung.

Tabel 14.

Uji t Pajak Restoran terhadap Pendapatan Asli Daerah

Coefficients

\begin{tabular}{|c|c|c|c|c|c|}
\hline \multirow{2}{*}{ Model } & \multicolumn{2}{|c|}{ Unstandardized Coefficients } & \multirow{2}{*}{$\begin{array}{c}\text { Standardized } \\
\text { Coefficients } \\
\text { Beta }\end{array}$} & \multirow{2}{*}{$\mathbf{T}$} & \multirow{2}{*}{ Sig. } \\
\hline & B & Std. Error & & & \\
\hline 1. (Constant) & $-4,060 \mathrm{E}+11$ & $3,153 \mathrm{E}+11$ & & $-1,288$ & ,288 \\
\hline Pajak Restoran & 13,858 & 2,437 & 957 & 5,687 & ,111 \\
\hline
\end{tabular}

a. Dependent Variable: PAD

Sumber: Diolah Kembali

Berdasarkan perhitungan diatas, maka diperoleh thitung untuk variabel $\left(\mathrm{X}_{2}\right)$ sebesar 5,687.Dengan tingkat signifikansi sebesar 5\% $(0,05)$ diperoleh tabel 12,706.sehingga thitung $<$ ttabel $=5,687<12,706$. Tingkat signifikansinya menunjukkan nilai signifikansi besar dari 0,05 yaitu 0,111 >0,05. Dengan demikian, Ho diterima atau Ha ditolak yang artinya tidak terdapat pengaruh yang signifikan antara variabel pajak hiburan terhadap variabel Pendapatan Asli Daerah Kota Bandung.

Tabel 15.

Uji t Pajak Hiburan terhadap Pendapatan Asli Daerah

\begin{tabular}{|c|c|c|c|c|c|}
\hline \multirow{2}{*}{ Model } & \multicolumn{2}{|c|}{ Unstandardized Coefficients } & \multirow{2}{*}{$\begin{array}{c}\text { Standardized } \\
\text { Coefficients } \\
\text { Beta }\end{array}$} & \multirow{2}{*}{$\mathbf{T}$} & \multirow{2}{*}{ Sig. } \\
\hline & B & Std. Error & & & \\
\hline 1. (Constant) & $-1,422 \mathrm{E}+12$ & $6,789 \mathrm{E}+11$ & & $-2,094$ & , 127 \\
\hline Pajak Hiburan & 70,453 & 17,193 & 921 & 4,098 & 226 \\
\hline
\end{tabular}

a. Dependent Variable: PAD

Sumber: Diolah Kembali 
Berdasarkan perhitungan diatas, maka diperoleh thitung untuk variabel $\left(\mathrm{X}_{3}\right)$ sebesar 4,098. Dengan tingkat signifikansi sebesar 5\% $(0,05)$ diperoleh $\mathrm{t}$ tabel 12,706 .sehingga $\mathrm{t}$ hitung $<\mathrm{t}$ tabel $=4,098<12,706$. Tingkat signifikansinya menunjukkan nilai signifikansi besar dari 0,05 yaitu 0,226 >0,05. Dengan demikian, Ho diterima atau Ha ditolak yang artinya tidak terdapat pengaruh yang signifikan antara variabel pajak hiburan terhadap variabel Pendapatan Asli Daerah Kota Bandung.

Tabel 4.16.

Uji F Pajak Hotel, Pajak Restoran, dan Pajak Hiburan terhadap Pendapatan Asli Daerah

\begin{tabular}{|l|c|c|c|c|c|}
\hline \multicolumn{7}{|c|}{ ANOVAa } \\
\hline \multicolumn{1}{|c|}{ Model } & Sum of Square & Df & Mean Square & F & Sig. \\
\hline $1 \mid$ Regression & $1,239 \mathrm{E}+24$ & 3 & $4,129 \mathrm{E}+23$ & 19,210 &, $002 \mathrm{~b}$ \\
\hline Residual & $2149 \mathrm{E}+22$ & 1 & $2,149 \mathrm{E}+22$ & & \\
\hline Total & $1,260 \mathrm{E}+24$ & 4 & & & \\
\hline
\end{tabular}

a. Dependent Variable: PAD

b. Predictors: (Constant), Pajak_Hiburan, Pajak_Hotel, Pajak_Restora

Sumber: Diolah Kembali

Berdasarkan perhitungan, maka diperoleh Fhitung sebesar 19,210, sedangkan F tabel dengan tingkat kesalahan sebesar 5\% $(0,05)$ adalah 19,16. sehingga diperoleh $\mathrm{F}_{\text {hitung }}$ $19,210>\mathrm{F}_{\text {tabel }} 19,16$. Jadi nilai probabilitas adalah $0,02<0,05$ yang berarti Ho diterima dan Ha ditolak, maka disimpulkan bahwa pajak hotel, pajak restoran, dan pajak hiburan (Pendapatan Sektor Pariwisata) secara bersamaan (simultan) memiliki pengaruh yang signifikan terhadap Pendapatan Asli Daerah (PAD).

\section{Kontribusi Pendapatan Sektor Pariwisata Terhadap Pendapatan Asli Daerah (PAD) Kota Bandung}

Pendapatan Sektor Pariwisata (pajak hotel, pajak restoran, dan pajak hiburan) adalah salah satu sumber Pendapatan Asli Daerah (PAD).

\section{Kontribusi Pendapatan Pajak Hotel terhadap Pendapatan Asli Daerah (PAD) Kota Bandung}

Pajak Hotel memiliki nilai realisasi tertinggi dan memiliki peran penting atas Pendapatan Asli Daerah (PAD) di Kota Bandung. Berdasarkan tabel 13 menunjukkan uji statistik $\mathrm{t}$ secara parsial sebesar 9,970 yaitu 9,970<12,706 ( t tabel) dengan tingkat signifikansi $>0,05$ yaitu $0,082>0,05$. Sehingga Ho diterima atau Ha ditolak yang artinya tidak terdapat pengaruh yang signifikan antara pajak hotel terhadap Pendapatan Asli Daerah Kota BandungHal ini sesuai dengan penelitian yang dilakukan Hadis Nirbeta (2014) dan Iftakhur Rizqiyah (2015) bahwa Pajak Hotel secara parsial tidak berpengaruh terhadap Pendapatan Asli Daerah Kota Tanjung Pinang dan Kota Semarang. 


\section{Kontribusi Pendapatan Pajak Restoran terhadap Pendapatan Asli Daerah (PAD) Kota Bandung}

Pajak Restoran memiliki nilai realisasi kedua tertinggi setelah Pajak Hotel dan memiliki peran penting atas Pendapatan Asli Daerah (PAD) di Kota Bandung. Berdasarkan tabel 14 menunjukkan uji statistik t secara parsial sebesar 5,687 yaitu 5,687 $<12,706$ (t tabel). dengan tingkat signifikansinya $>0,05$ yaitu $0,111>0,05$. Sehingga Ho diterima atau Ha ditolak yang artinya tidak terdapat pengaruh yang signifikan antara pajak restoran terhadap Pendapatan Asli Daerah Kota Bandung.Hal ini sesuai dengan penelitian yang dilakukan Hadis Nirbeta (2014) bahwa Pajak Restoran secara parsial tidak berpengaruh terhadap Pendapatan Asli Daerah Kota Tanjung Pinang.

\section{Kontribusi Pendapatan Pajak Hiburan terhadap Pendapatan Asli Daerah (PAD) Kota Bandung}

Pajak Hiburan memiliki nilai realisasi yang cukup tinggi dan memiliki peran penting atas Pendapatan Asli Daerah (PAD) di Kota Bandung. Berdasarkan tabel 15 menunjukkan uji statistik t secara parsial sebesar 4,098 yaitu 4,098 < 12,706 (t tabel) dengan tingkat signifikansinya $>0,05$ yaitu $0,226>0,05$. Sehingga Ho diterima atau Ha ditolak, artinya tidak terdapat pengaruh yang signifikan antara pajak hiburan terhadap Pendapatan Asli Daerah Kota Bandung. Hal ini sesuai dengan penelitian yang dilakukan Deny Razianti (2015) bahwa secara Pajak Hiburan secara parsial tidak berpengaruh terhadap Pendapatan Asli Daerah Kabupaten Bintan.

Tabel 17.

Kontribusi Pendapatan Sektor Pariwisata terhadap Pendapatan Asli Daerah (PAD) Kota Bandung

\begin{tabular}{|c|r|r|c|c|}
\hline $\begin{array}{c}\text { Tahun } \\
\text { Anggaran }\end{array}$ & $\begin{array}{c}\text { Pendapatan Sektor } \\
\text { Pariwisata }\end{array}$ & $\begin{array}{c}\text { Pendapatan Asli } \\
\text { Daerah (PAD) }\end{array}$ & $\begin{array}{c}\text { Kontribusi Sektor } \\
\text { Pariwisata terhadap } \\
\text { PAD }\end{array}$ & $\begin{array}{c}(\%) \\
\text { Trend }\end{array}$ \\
\hline 2011 & 226.793 .382 .411 & 667.275 .019 .226 & 33.99 & 0 \\
\hline 2012 & 274.642 .290 .437 & 820.714 .860 .033 & 33.46 & $(0.53)$ \\
\hline 2013 & 333.957 .815 .217 & 820.714 .860 .033 & 23.14 & $(10.32)$ \\
\hline 2014 & 387.281 .925 .337 & 1.716 .057 .298 .378 & 22.61 & $(0.66)$ \\
\hline 2015 & 447.116 .954 .456 & .989 .000 .000 .00022 & 1.48 & $(0.13)$ \\
\hline Jumlah & 1.669 .792 .367 .858 & 6.635 .822 .415 .960 & 135.68 & \\
\hline
\end{tabular}

Sumber: Diolah Kembali

Berdasarkan tabel di atas disimpulkan bahwa kontribusi penerimaan pendapatan sektor pariwisata terhadap Pendapatan Asli Daerah (PAD) mulai tahun 2011 sampai 2015 mengalami penurunan walaupun jumlahnya dari tahun ke tahun meningkat. Penurunan ini disebabkan dengan adanya kebijakan pemerintah terkait pelarangan pelaksanaan rapat di hotel, adanya pembatasan jam operasional Tempat Hiburan, Adanya 9 WP Tempat Hiburan yang menutup tempat usahanya, 4 WP Tempat Hiburan yang menutup sementara tempat 
usahanya, serta tingkat kunjungan (occupancy) menurun. Namun secara keseluruhan bahwa kontribusi penerimaan pendapatan sektor pariwisata (pajak hotel, pajak restoran, dan pajak hiburan) mempengaruhi dan berperan dalam meningkatkan Pendapatan Asli Daerah Kota Bandung dari 9 mata pajak.

Berdasarkan tabel 12.disimpulkan bahwa koefisien determinasi (r2) sebesar 98,3\%. Hasil ini menunjukkan bahwa kontribusi penerimaan pendapatan sektor pariwisata (pajak hotel, pajak restoran, dan pajak hiburan) terhadap variabel Pendapatan Asli Daerah sebesar 98,3\%. Sedangkan sisanya sebesar 1,7\% dipengaruhi oleh variabel lain yang tidak diteliti dalam penelitian ini. Sedangkan berdasarkan tabel 16 disimpulkan bahwa hasil uji statistik F secara simultan (bersamaan) sebesar 19,210 yang berarti 19,210>19,16 (F tabel) dengan tingkat signifikansi (sig) sebesar 0,002. Sehingga Ho diterima dan Ha ditolak, yang artinya terdapat pengaruh yang signifikan dan hubungan yang kuat antara pajak hotel, pajak restoran, dan pajak hiburan yang merupakan komponen Pendapatan Sektor Pariwisata terhadap Pendapatan Asli Daerah (PAD). Hal ini sesuai dengan penelitian Iftakhur Rizqiyah (2015) bahwa secara simultan (bersama-sama) Pajak Hotel, Pajak Restoran, dan Pajak Hiburan memiliki pengaruh yang signifikan terhadap variabel Pendapatan Asli Daerah (PAD) Kota Semarang.

\section{SIMPULAN}

Berdasarkan hasil pengujian dapat disimpulkan:

1. Realisasi penerimaan pendapatan sektor pariwisata di Kota Bandung pada tahun 2011 sampai dengan 2015 mengalami peningkatan dengan tingkat pertumbuhan yang berbeda-beda dengan rata-rata efektivitas sebesar 106,62\%.Penerimaan pajak hotel, pajak restoran, dan pajak hiburanmencapai target pada tahun 2011 sampai tahun 2013. Pada tahun 2014 dan 2015 tidak mencapai target disebabkan oleh adanya larangan mengadakan rapat di hotel, pembatasan jam operasional tempat hiburan, 9 WP tempat hiburan menutup sementara dan 4 WP menutup tempat usahanya sehingga tingkat kunjungan (occupancy) hotel menurun.

2. Realisasi Pendapatan Asli Daerah (PAD) Kota Bandung mengalami kenaikan setiap tahunnya dengan rata-rata efektivitas 105,31\%. Pendapatan Asli Daerah (PAD) Kota Bandung mencapai target di tahun 2011 sampai tahun 2013. Namun di tahun 2014 dan 2015 tidak mencapai target. Dengan rata-rata pendapatan sebesar 105,31\% artinya kinerja dalam pemungutan atas Pendapatan Asli Daerah (PAD) KotaBandung baik.

3. Hasil analisis data kontribusi pendapatan sektor pariwisata yang meliputi pajak hotel, pajak restoran, dan pajak hiburansecara bersama-sama (simultan) terhadap Pendapatan Asli Daerah (PAD) Kota Bandung, diperoleh F hitung sebesar 19,210 dengan tingkat signifikansi 0,002 . Jadi nilai probabilitas adalah $0,002<0,05$ yang 
berarti Ho diterima dan Ha ditolak, yang artinya terdapat pengaruh yang signifikan antara pajak hotel, pajak restoran, dan pajak hiburanyang merupakan komponen dari Pendapatan Sektor Pariwisata terhadap Pendapatan Asli Daerah (PAD). Hasil uji determinasi $98,3 \%$. Sedangkan sisanya sebesar1,7\% dipengaruhi oleh variabel lain yang tidak diteliti dalam penelitian. Hal ini menunjukkan bahwa apabila pendapatan pada sektor pariwisata meningkat, maka Pendapatan Asli Daerah (PAD) akan meningkat.

\section{DAFTAR PUSTAKA}

Jaya, Gde Bhaskara Perwira dan Widanta, AA Bagus Putu.2014. Analisis Faktor-Faktor Yang Berpengaruh Terhadap Pendapatan Asli Daerah (PAD) Kota Denpasar. E-Journal EP Unud, 3.5.201-208

Mardiasmo. 2011. Perpajakan. Edisi Revisi. Yogyakarta: Andy Offset

Muharomah, Siti. 2006. Analisis Pengaruh Pendapatan Asli Daerah (PAD) Terhadap Kinerja Keuangan Pada Pemerintah Kabupaten dan Kota di Propinsi Sumatera Selatan. Jurnal Ilmiah. Forum Bisnis dan Kewirausahaan. STIE MDP

Nirbeta, Hadis. 2014. Pengaruh Pemungutan Pajak Reklame, Pajak Hotel, Pajak Hiburan, , Pajak Penerangan Jalan, Pajak Restoran dan Pajak Terhadap Pendapatan Asli Daerah Kota Tanjung Pinang Periode 2010-2012. Universitas Maritim Raja Ali Haji

Peraturan Daerah Nomor 20 Tahun 2011 tentang Pajak Daerah

Razianti, Deny. 2015. Pengaruh Pajak Hotel, Pajak Hiburan, Pajak Restoran, Pajak Penerangan Jalan, Pajak Mineral Bukan Logam dan Batuan, Pajak Parkir dan Bea Perolehan Hak Atas Tanah dan Bangunan Terhadap Pendapatan Asli Daerah Kabupaten Bintan Periode 2011-2014. Universitas Maritim Raja Ali Haji

Rizqiyah, Iftakhur. 2015. Pengaruh Pajak Hotel, Pajak Restoran, , Pajak Hiburan, Pajak Reklame dan Pajak Parkir Terhadap Pendapatan Asli Daerah Kota Semarang Periode 2009-2013. Universitas Dian Nuswantoro

Siahaan, Pahala Marihot. 2013. Pajak Daerah dan Retribusi Daerah. Edisi Revisi. Jakarta: Raja Gravindo Persada

Spillane, James J. 1987. Pariwisata Indonesia. Yogyakarta. Kanisius

Suandy, Erly. 2011. Hukum Pajak. Jakarta: Salemba Empat

Undang- Undang Nomor 34 Tahun 2000 tentang Pemerintahan Daerah

Undang- Undang Nomor 32 Tahun 2004 tentang Pemerintahan Daerah

Undang- Undang Nomor 33 Tahun 2004 tentang Perimbangan Keuangan antara Pemerintahan Pusat dan Pemerintahan Daerah 
Undang- Undang Nomor 10 Tahun 2009 tentang Kepariwisataan

Undang- Undang Nomor 28 Tahun 2009 tentang Pajak Daerah dan Retribusi Daerah

Yoeti, Oka A. 2014. Pengantar Ilmu Pariwisata. Bandung: Angkasa 